DEMOGRAPHIC RESEARCH

VOLUME 38, ARTICLE 61, PAGES 1885-1932

PUBLISHED 12 JUNE 2018

http://www.demographic-research.org/Volumes/Vol38/61/

DOI: 10.4054/DemRes.2018.38.61

Research Article

\title{
Migration responses of immigrants in Spain during the Great Recession
}

\section{Victoria Prieto-Rosas \\ Joaquín Recaño \\ Doris Cristina Quintero-Lesmes}

(C) 2018 Prieto-Rosas, Recaño \& Quintero-Lesmes.

This open-access work is published under the terms of the Creative Commons Attribution 3.0 Germany (CC BY 3.0 DE), which permits use, reproduction, and distribution in any medium, provided the original author(s) and source are given credit.

See https://creativecommons.org/licenses/by/3.0/de/legalcode. 


\section{Contents}

1 Introduction 1886

2 Background 1889

2.1 Internal migration versus international emigration of foreign-born 1891

2.2 The impact of the economic crisis on the Spanish labour market 1893

3 Data and methods 1894

$4 \quad$ Results 1903

4.1 Transformations in the intensity of internal and international 1903

4.2 Individual and contextual factors associated with interregional and 1906 international migration

5 Conclusions 1916

6 Acknowledgements 1920

$\begin{array}{ll}\text { References } & 1921\end{array}$

$\begin{array}{ll}\text { Appendix } & 1925\end{array}$ 


\title{
Migration responses of immigrants in Spain during the Great Recession
}

\author{
Victoria Prieto-Rosas ${ }^{1}$ \\ Joaquín Recaño ${ }^{2}$ \\ Doris Cristina Quintero-Lesmes ${ }^{3}$
}

\begin{abstract}
OBJECTIVE

We aim to describe the impact of the crisis on the intensity and demographic profile of internal migration and different forms of international emigration.

\section{METHODS}

Using microdata from the Residential Variation Statistics for 2006-2013, we estimate the rates of interregional migration and the different forms of international emigration, including return migration and remigration. We used multinomial regressions.
\end{abstract}

\section{RESULTS}

Return migration and emigration to an unknown destination increased significantly with respect to interregional mobility at early and late stages of the crisis. In contrast, interregional migration was more likely than international emigration before the first stage. Regardless of birthplace, Spanish citizenship is an asset for mobility within Spain and the EU for all foreign-born individuals, and for emigration to non-EU countries for Cubans. Finally, emigration to an unknown destination resembles return migration in its composition by sex, age, and origin.

\section{CONTRIBUTION}

First, we discuss the chronology of migration responses, while showing that the prevalence of each varies according to citizenship status and the stages of the economic downturn. Second, it notes the similarities between emigration to an unknown destination and return migration captured by the Spanish Residential Variation Statistics, supporting the argument that the former is a kind of return adopted by

\footnotetext{
${ }^{1}$ Programa de Población, Universidad de la República, Montevideo, Uruguay.

Email: victoria.prieto@cienciassociales.edu.uy.

${ }^{2}$ Departament de Geografia and Centre d'Estudis Demogrâfics, Universitat Autónoma de Barcelona, Spain. Email: joaquin.recano@uab.es.

${ }_{3}^{3}$ Fundación Cardiovascular de Colombia, Bucaramanga, Colombia. Email: dorisquintero@fcv.org.
} 
immigrants without Spanish citizenship. Third, although Spain is one of the European countries with a significant share of foreign-born populations and also one of the few countries with statistics to examine both internal migration and international emigration, this paper constitutes the first attempt to do so.

\section{Introduction}

Migration responses to the 2008 Spanish financial crisis have generated considerable interest among scholars in this field, with the greatest attention paid to return migration (Cerrutti and Maguid 2016; Recaño and Jáuregui 2014; López de Lera and PérezCarames 2015; Recaño, Roig, and de Miguel 2015), followed by remigration (Larramona 2013; Mateos 2015; Pereira 2012; Mas-Giralt 2016). However, with a few exceptions, the changes in internal migration have been largely overlooked (QuinteroLesmes 2016; Bayona-i-Carrasco, Thiers Quintana, and Avila Tàpies 2017).

Joining the literature to bridge the gap between internal migration and international emigration (King, Skeldon, and Vullnetari 2008; Czaika and de Haas 2012; Czaika 2012), this paper argues that international emigration, which includes return migration and remigration to a third country, is as important as internal migration in assessing the whole range of possible mobility responses in times of economic crisis. Although the simultaneous study of both types of migration has not been addressed during this type of economic context before, the Spanish case provides a context in which it is possible to do so, given the large foreign-born population that has acquired Spanish citizenship and the availability of individual microdata on interregional migration and international emigration, which is rarely available in current statistics.

In addition, acknowledging that the boom in emigration from Spain did not follow immediately on from the economic collapse, our first hypothesis is that internal migration was a preferred response at the initial stage of the crisis (Recaño and Jáuregui 2014; Recaño, Roig, and de Miguel 2015). This hypothesis arises from previous evidence for male Mexican migrants' migration responses to the recession in the United States. Torre-Cantalapiedra and Giorguli (2015) found that return to Mexico was an alternative response to internal migration within the United States. Based on individual longitudinal data for the period from 1942 to 2011, they assessed the preference for these reactions and pointed to return migration as migrants' preferred strategy when facing the US economic crisis. However, their findings also acknowledged significant transformations in the intensity and direction of the internal migration of Mexicans in 
the United States. ${ }^{4}$ We share an interest with this last article in considering both internal and international mobility responses to the economic recession. However, our study differs in terms of the approach adopted. We are unable to establish causality for competing risk of both types of event since we analysed cross-sectional data from the Residential Variation Statistics published by the Spanish National Statistics Office, and this data does not include information on people who do not move and is not longitudinal. Instead, we compare the probability of any form of international emigration versus internal migration, an approach similar to that used in Larramona's study of emigration from Spain for 2002-2009 (Larramona 2013). In contrast with this author's work, we have used data from 2006 to 2013, covering a period when data for emigration was better captured by the Residential Variation Statistics - the same data source used by Larramona. She has assessed the determinants of both return migration and remigration from Spain, but her work neither accounts for internal migration nor distinguishes between remigration and emigration to an unknown destination. Additionally, we pay attention to the patterns of behaviour of Latin American people, because they have represented most of the growth in the foreign population in Spain for nearly a decade, they are a heterogeneous group in respect to dates of arrival and demographic characteristics (Prieto and López-Gay 2015), and, together with Africans, they have led the return migration outflow since 2009. They also contributed to the recovery of internal migration before the recession and continued to play a significant role following the advent of the crisis: between 1998 and 2014, the total number of movements among foreign-born individuals was three times higher than that observed among the native population (Silvestre and Reher 2014). During the crisis, return migration and remigration flows of the native and foreign-born populations increased, whereas the intensity of internal migration first declined and then remained somewhat stable after 2008, despite some variations by country of origin (Recaño 2016). Another consequence of the economic collapse was expressed through changes in the geographic patterns of immigrants' internal migration. Before the crisis, Madrid, Barcelona, and the Mediterranean coast, together with the Canary and Balearic Islands, were the main immigrant-receiving regions. After 2008, only Madrid, Barcelona, and the Basque Country have remained in this group (Quintero-Lesmes 2016; Silvestre and Reher 2014).

In this paper, we use a restrictive definition of internal migration that considers the residential change between autonomous communities and excludes all the migration within these first subnational levels (intraregional migration), which from 2006 to 2013

\footnotetext{
${ }^{4}$ The individual determinants for both types of migration indicate that duration of stay, legal status in the receiving country, and occupation are the main factors explaining mobility trends from 1946 to 2011.
} 
accounted for $67.9 \%$ of all internal mobility. ${ }^{5}$ This selection responds to the fact that, in Spain, interregional movements are driven by economic determinants, while intraregional migration is more associated with residential preferences typically associated with swings in the housing market (Recaño and Roig 2006). With regard to international emigration, we consider four different types: (1) return migration, in which the migrant left Spain in the direction of his or her country of birth; (2) remigration to another EU country, in which the migrant left Spain in the direction of any other EU country; (3) remigration to a non-EU country, in which the migrant left Spain in the direction of countries that do not belong to the group of 27 other countries comprising the European Union; (4) emigration to an unknown destination. The last group differs from the previous categories in its statistical nature, as it is not a movement reported by the migrant himself or herself but the outcome of a clean-up operation conducted by the National Statistics Office (Ortega, Domingo, and Sabater 2013; Gil 2010). Further explanation of this category, including the normative framework that underpins such operations, will be provided in the data and methods section. However, two factors must be borne in mind. First, this type of emigration has not been modelled before, despite representing more than half the total number of foreigners' departures from Spain. Second, it includes all returns, remigrations to EU, and emigrations to non-EU destinations but differs from the others in relation to the citizenship of the migrants it affects, as it accounts for only non-Spanish citizens, who are required to update their listings in the Population Register every two or five years depending on their citizenship status. We believe that the inclusion of this category in the analysis is one of the main contributions of this paper, which aims to explore the demographic characteristics that distinguish the foreign immigrants who leave Spain without reporting their destination from those who do so.

The second hypothesis of this paper argues that the departures to an unknown destination may converge with the sociodemographic profile of returnees in terms of age, sex, timing, and contextual determinants, differing only in citizenship status. The administrative operation starts this type of delisting from the Population Register; the characteristics of this operation support the idea that only foreign-born immigrants with Spanish or other EU citizenship have incentives to report their departure or register at Spanish consulates abroad, while those who leave Spain as non-EU citizens who do not need to report their migration are "emigrations to an unknown destination."

The methodological strategy adopted followed two steps to assess the impact of the stages of the economic recession on the intensity and profile of the migrants

\footnotetext{
${ }^{5}$ For 2006-2013, the number of movements that occurred within the same province among the foreign-born population was 2,235,545 (55.8\%) and the number of movements between provinces and within the borders of the same autonomous community was 308,993 (7.7\%). The remaining $1,455,376$ movements form the share of internal mobility that we are considering here for the bivariate and multivariate analyses and represent about $36.4 \%$ of all internal migration.
} 
experiencing all forms of mobility just described. First, we discuss the intensity of each form of mobility by birthplace, citizenship, and stage of the economic recession. Second, using multinomial logistic regression, we analyse the demographic characteristics of migrants and the incidence of the region of origin (autonomous community) on the probability of moving abroad over moving internally, first for all foreign-born individuals and second for Latin Americans. To explain how the prevalence of each type of migration response varies according to the different contexts of origin and stages of the economic downturn, we have included three dummy variables for every period: (1) pre-crisis (2006-2008); (2) economic collapse (20092010); and (3) recession (2011-2013). In this way, we tested the first hypothesis using the chronology of mobility responses. The comparison between the expected probabilities of "departure to an unknown destination" and the probabilities for return migration and remigration provides evidence to test the second hypothesis, stating that "departure to an unknown destination" resembles return migration more than remigration to EU or non-EU destinations.

The paper is structured as follows. In the next section, we discuss the literature on the evidence for return migration, remigration, and internal migration of foreign-born populations in Spain, with a focus on Latin American immigrants. We then present the data and methods used in the study, before going on to discuss the key findings regarding the intensity of the internal migration and international emigration of foreignborn populations. In the penultimate section, we introduce the results of the multivariate analysis of the associations between individual and contextual characteristics with different forms of international emigration. Finally, we provide a general discussion of the results.

\section{Background}

The precise causes and effects of migration between countries have long been a topic of debate. Researchers have now found that the global economic crisis of 2008 has had an effect too (Tilly 2011). During the recession, migratory flows to the richest countries "collapsed abruptly," which is the opposite of what some theories would have predicted. However, return migration to countries of origin appears to have increased markedly only when round-trip movements were relatively easy, as in the European Union (Bertoli, Brücker, and Moraga 2013; Domínguez-Mujica, Guerra-Talavera, and Parreño-Castellano 2012).

The economic crisis seems to have affected flows in several countries, particularly those where the recession began earlier and was more extensive. Evidence of the decline in labour migration flows comes from the United Kingdom, Ireland, and Spain. 
In other countries, the effects of the economic slowdown on migration trends are not yet visible. Irregular migratory flows appear to have declined in some countries, especially in the United States (Arslan et al. 2014).

Labour market conditions have deteriorated in all the countries of the Organization for Economic Co-operation and Development (OECD) because of the economic crisis. This situation has called into question the progress made in the 2000s in terms of the labour market outcomes of immigrants in several OECD countries, especially Spain, Ireland, the United States, and the United Kingdom, all countries where immigrant labour played a key role during the last period of economic expansion (Arslan et al. 2014).

In Spain, international migration flows during the crisis have followed two different trends: inflow declined because of the deterioration of the economic and social situation, while emigration of the foreign-born population experienced a sharp increase. When considering the population stock, in January 2013, for the first time in recent Spanish history, the registered population decreased by 3.3\% due to the loss of 190,020 foreign residents (Quintero-Lesmes 2016). Moreover, the Latin American workforce diminished by approximately $16.3 \%$ following the crisis, and the share of Latin Americans in the total foreign-born population also declined. This reduction was particularly pronounced in Madrid, Barcelona, and other cities located along the Mediterranean coast (Torres-Pérez, Moncusí, and Esteban 2013).

The growth in the outflow of foreign-born people from Spain coincided not only with the decline of employment in the sectors in which most Latin Americans were working, construction and services, but also with the start of public aid encouraging return migration for immigrants. ${ }^{6}$

Previous research has shown that the migration responses of immigrants to economic shocks can be very diverse, varying over time and among individuals (Pandit 1997; Mas-Giralt 2016; Zimmermann and Zaiceva 2012; Czaika 2012; Czaika and de Haas 2012; Pereira 2012; Calnan and Painter 2016). According to the first hypothesis presented in the introduction, we would have expected internal migration to be preferred during the initial stages of the Spanish recession, but once unemployment became endemic, all forms of international emigration increased significantly to become the preferred response among immigrants. Therefore, in the following section,

\footnotetext{
${ }^{6}$ At this time, three programmes were developed targeting potential returnees from Spain: 1) the voluntary return programme for humanitarian reasons, which was created in 2003 and supported by the IOM and several NGOs; 2) the Social Security programme, in force since 2008, which granted advance payment of accumulated unemployment subsidies for non-EU28 workers; and 3) the voluntary return programme, focused on the foreign-born population with solid business plans, which was launched in 2010. Furthermore, different Latin American countries promoted return migration via specific return programmes, although their impact has been very limited (González-Ferrer 2014; Czaika and de Haas 2013; Koser and Kuschminder 2015; Recaño and Jaúregui 2014).
} 
we review the trends of immigrants' internal migration and international emigration, paying attention to their timing as well as to the impact of the Spanish economic cycle on the latter. Although we focus mainly on Latin American migrants, we also discuss the impact on other foreign-born populations.

\subsection{Internal migration versus international emigration of foreign-born individuals}

The intensity of the internal migration of immigrants in Spain has declined since 2008, when the economy showed the first signs of destabilization (Recaño 2016; Bayona-iCarrasco, Thiers Quintana, and Avila-Tàpies 2017). In this respect, Latin Americans represented the population of foreign origin that experienced the smallest impact of the crisis. The summary measures of migration intensity for this region of origin declined at a lower rate than those for the rest of the foreign-born population, and Bolivians, Argentinians, and Dominicans were the three most affected populations. The only exceptions were Colombians and Ecuadorians, whose intensity rates were even higher than those of Spaniards. Furthermore, the average distance of internal migration increased in the period from 2009 to 2011, and most of the movement occurred from the Mediterranean area and the Canary Islands - the most affected regions due to the increase in unemployment rates - to the Basque Country, Catalonia, and Madrid (Quintero-Lesmes 2016).

When internal migration is compared to international emigration responses, the effects of individual characteristics vary significantly. For example, a study of Mexican immigrants in the United States has shown that regular residence status or naturalization reduces the odds of return migration and increases the probability of experiencing an internal migration within the United States (Torre-Cantalapiedra and Giorguli 2015). Although the simultaneous study of the drivers of international emigration and internal migration has no precedent in Spain, research on these individual patterns of behaviour has shown that being a Spanish citizen increases the odds of experiencing nonreturn forms of emigration ${ }^{7}$ among the foreign-born population (Larramona 2013; Recaño, Roig, and de Miguel 2015) and reduces the odds of internal migration (QuinteroLesmes 2016; Recaño and de Miguel 2012). Regarding the determinants of mobility in the region of origin, the sectoral structure of the local economy has also been shown to play a differential role for internal migration and international emigration. The internal migration rates within the agricultural regions of the United States and Spain are particularly high among the foreign-born population (Durand and Massey 2003; Torre-

\footnotetext{
${ }^{7}$ This is the term used by Larramona (2013) to describe the outflow of remigration to a third country that is different from the country of birth and emigration from Spain to an unknown destination captured by the Spanish Residential Variation Statistics.
} 
Cantalapiedra and Giorguli 2015; Recaño and Roig 2006; Recaño and de Miguel 2012). Conversely, in both contexts, return migration has been shown to be higher from regions where services or manufacturing sectors correspond to larger shares of GDP (Torre-Cantalapiedra and Giorguli 2015; Recaño, Roig, and de Miguel 2015) or higher unemployment rates (Larramona 2013).

Although remigration increased following the onset of the economic crisis, return migration was preferred over onward international migration (Recaño, Roig, and de Miguel 2015). Remigration rates have been shown to be higher for dual citizens (Spanish and other non-EU28 citizens) than for non-EU28 $8^{8}$ citizens. The outflow to the United Kingdom, followed by Germany, France, Switzerland, and the Netherlands, represented the largest migration rates for Latin Americans. The United States and Italy remained important destinations for this population's emigration from Spain, but the migration to these countries declined slightly following the crisis. According to Recaño, Roig, and de Miguel (2015), the increase observed in the male onward migration rate was concentrated in the Mediterranean provinces and inner rural areas, whereas among women growth at the same rates was not associated with a specific geographic area but instead was dispersed over the country.

Recently, Larramona (2013) has estimated the probability of return migration compared to nonreturn emigration for the period from 2002 to 2009. She modelled this together with the odds of experiencing remigration or departures from Spain for which a migrant did not provide information regarding destination. The results show that age has a positive effect on the probability of return migration, whereas nonreturn international emigration is rare at advanced ages. Regarding sex, her findings indicate that females are more prone to experiencing remigration than men, who have a higher probability of returning. Similarly, citizenship distinguishes the profiles of returnees from other emigrants, since EU28 citizens have higher odds of returning than nonEU28 citizens. Finally, individuals born in Asia, Africa, or Latin America were less likely to return to the country of their birth from 2002 to 2009; instead, they preferred to leave Spain and move to a third country or leave without informing the Spanish Population Register of their departure. On a more aggregate level, Larramona (2013) uses as controls both the size of municipality of origin and destination (country). Her findings suggest that individuals leaving smaller localities had fewer chances of experiencing nonreturn forms of emigration and preferred to return to their country of birth.

\footnotetext{
${ }^{8}$ The 28 member-states of the European Union are Austria, Belgium, Bulgaria, Croatia, Cyprus, the Czech Republic, Denmark, Estonia, Finland, France, Germany, Greece, Hungary, Ireland, Italy, Latvia, Lithuania, Luxembourg, Malta, the Netherlands, Poland, Portugal, Romania, Slovakia, Slovenia, Spain, Sweden, and the United Kingdom. Here, we will refer to non-EU28 when speaking about any country other than those in the EU28.
} 


\subsection{The impact of the economic crisis on the Spanish labour market}

The financial crisis has destabilized the social integration process of immigrants through its impact on unemployment, quality of employment, and poverty. Unemployment rates were particularly severe among foreign-born individuals, who experienced a $36.6 \%$ unemployment rate compared to the $24.3 \%$ rate faced by natives. This gap corresponds to the overrepresentation of immigrant workers in the most affected economic sectors, construction and services, which also have the highest concentrations of temporary and unskilled jobs (Aysa-Lastra and Cachón 2012; Pajares 2010; IOM 2012).

In the first phase of the crisis, 2008-2010, the most common strategy involved an adjustment to temporary employment, which facilitated entry into the labour market for many immigrants but triggered the departure of workers who were already employed. Since then, the loss of employment has been higher among permanent jobs. However, there are differences by country of origin among immigrants. In 2011, the unemployment rate of Latin Americans was higher than that of natives $-28.5 \%$ and $19.5 \%$ respectively - although it remained the lowest compared to that of other nonEU28 immigrants. ${ }^{9}$

We should mention that this economic crisis hit an already segmented labour market. The recent Latin American immigration to Spain responded to the dynamism of some sectors of the Spanish labour market, and from the very beginning these immigrants' integration into Spain was segmented. Most Latin Americans took lowskilled jobs, whereas new cohorts of highly educated Spanish workers engaged in upward social mobility (Bernardi, Garrido, and Miyar-Busto 2011). It was the dynamism of low-skilled jobs, especially in construction and domestic services, that ensured the rapid integration of the foreign-born individuals who arrived prior to 2008 (Rodríguez-Planas and Nollenberger 2014). Before the crisis began, the activity and employment rates among Latin American immigrants were similar to those of the native population and higher than those of other foreign-born groups (Muñoz-Comet 2014).

With the advent of the recession, Latin Americans were not immune to the decline in employment and even the most educated suffered from the depreciation of their educational credentials (Cebolla-Boado, Miyar-Busto, and Muñoz-Comet 2015). Moreover, the crisis severely reduced the bargaining power of foreign workers, who accepted worse labour conditions (Aysa-Lastra and Cachón 2012) or showed more flexibility in terms of geographic and sectoral mobility in the labour market (QuinteroLesmes 2016).

The segmentation of the Spanish labour market also responded to other structural factors that preceded the arrival of Latin Americans. This labour market was split into a

\footnotetext{
${ }^{9}$ The unemployment rate of Africans reached 49.3\% (Colectivo Ioé 2012: 72).
} 
first sector with skilled jobs, high wages, and permanent contracts, and a second sector with a high concentration of less-skilled workers who received worse pay and were exposed to high turnover rates (Muñoz-Comet 2014). In any case, the recession worsened the labour segmentation already described, widening the gap between Spanish and foreign-born workers and fundamentally affecting males employed in lowskilled sectors, such as construction (Aysa-Lastra and Cachón 2012). Foreign-born females were less affected by the decline in employment, probably due to their overrepresentation in economic sectors that are less sensitive to recession, such as domestic work and care for the elderly.

\section{Data and methods}

To measure the internal migration within and international emigration from Spain, we have used the Residential Variation Statistics microdata (in Spanish, Estadística de Variaciones Residenciales). This data does not count migrants but migrations. Based on this data, and acknowledging the restrictions entailed, as shown in Figure 1, this article uses the following classifications for migration: (0) internal migration as changes between autonomous communities (interregional migration); (1) return migration, referring to the return to the country of birth; (2) remigration to EU28 countries, referring to emigration from Spain to another EU28 member state different from the country of birth; (3) remigration to non-EU28 countries, relating to emigration from Spain to non-EU28 countries that are also different from the country of birth; and (4) emigration to an unknown destination. Investigation of the last of these presents a challenge in terms of modelling migration outcomes since we are dealing with a pattern of behaviour that is a blend of return migration and remigration, and the rationales that apply to each may differ. However, given that this type of movement applies to approximately eight out of ten cases in the dataset, we decided to include it as an outcome to ensure the accurate estimation of the probability of migrating to both kinds of destinations: the known and the unknown. 
Figure 1: Migration outcomes to be modelled in multinomial regression

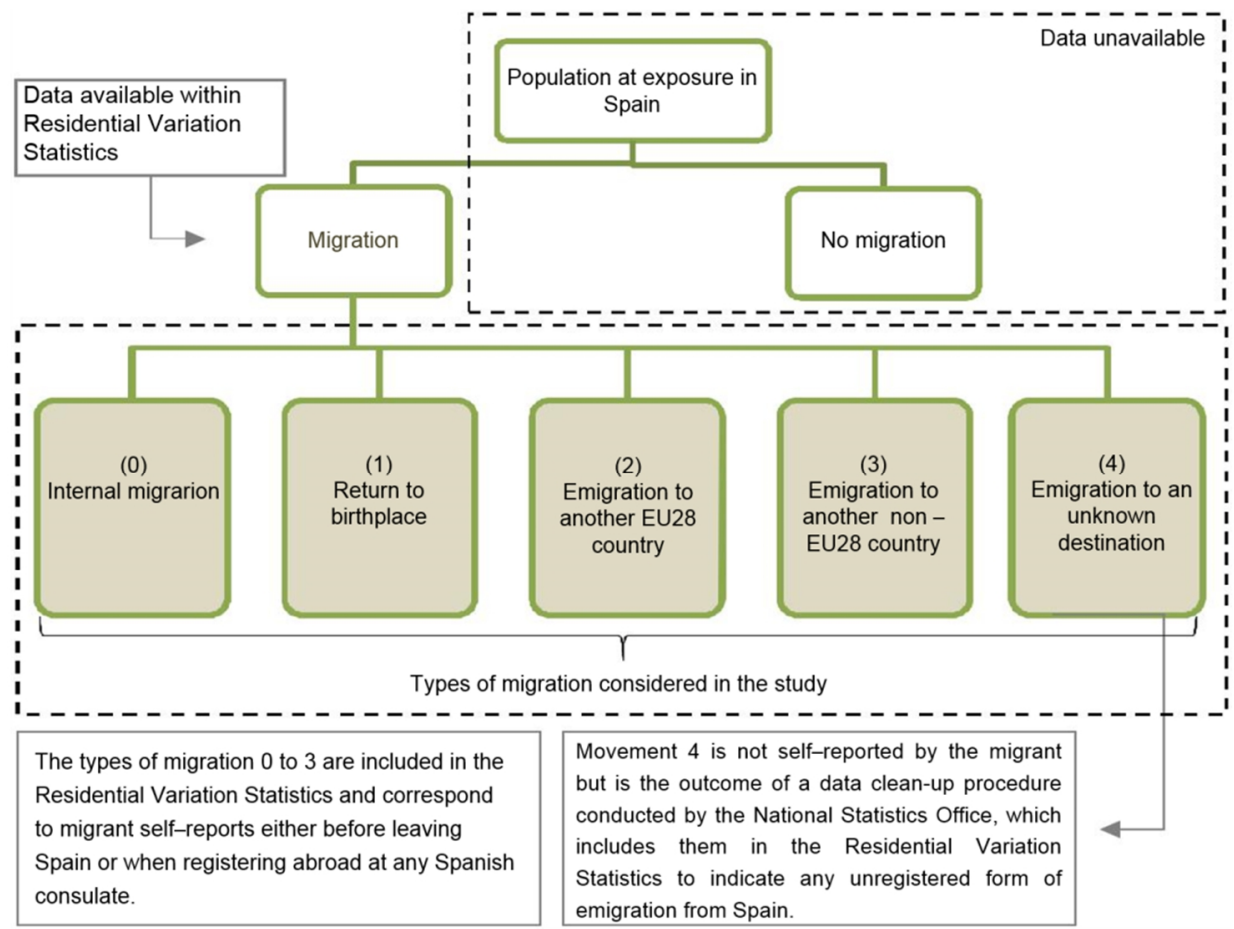

Source: Own elaboration

In general, migrants have little incentive to report their migration to the authorities of the country from which they have emigrated (Thierry et al. 2005). Moreover, it is in the interest of many immigrants to remain on the Spanish Population Register, which implies "proof" of residence in the country, so as not to lose future rights. To correct the shortcomings of the direct measurement of external emigration flows derived from the Residential Variation Statistics, in 2006 the Spanish government established that nonEU foreigners without permanent residence authorization would be obliged to renew their registration at the Municipal Register every two years. In the case of failure to carry out this renewal, town councils had to declare the expiration of the registration, which was automatically assimilated into the category of emigration abroad to an unknown destination. Between the last entry in the Population Register and the end of the administrative process that assumed cancellation due to expiration, there was therefore a minimum time lag of two years. This new procedure was called "delisting," or, in Spanish, baja por caducidad (box 4 in Figure 1), and it had two limitations: exit 
from Spain could have occurred at any point within that minimum two-year interval and no data was provided regarding country of destination. Overall, for the period under study, 2006-2013, we know the country of destination for only $24 \%$ of the departures from Spain.

To study the intensity of internal migration and international emigration, we estimated migration rates by sex, age, country of birth, and citizenship, with the aim of describing changes in the demographic and geographic patterns of migration before and during the crisis. In addition, to assess the individual and contextual characteristics associated with the different migration responses, we estimated two different multinomial regression models. The first was specified for all foreign-born populations and included controls for individual characteristics, such as sex, age, citizenship, birthplace, and time of migration, as well as contextual variables. The second was similar to the first but was restricted to Latin American-born individuals. Both models make it possible to predict the probability of opting for international emigration as opposed to the probability of changing region of residence within Spain.

Regarding the model restricted to Latin American immigrants, though the selection of a country of reference for "country of birth" will always be somewhat arbitrary, we have chosen as the reference category the largest group of Latin American origin, Ecuadorians. With the reference category for citizenship, we decided to compare all citizenship statuses, taking Spanish status as the least vulnerable to economic recession. However, in the model for Latin Americans, we merged the categories of Spanish and EU citizens because the largest movement experienced by this group, which is emigration without reporting destination, includes only non-Spanish citizens, except for eight outliers of Latin American origin, who, despite being Spanish citizens, are counted within the category "emigration to an unknown destination."

Although data on the international emigration of the foreign-born population has been available since 2004, the values for 2004-2005 are underestimated, so we have chosen to focus on 2006-2013. The estimation of rates required the combined use of the Residential Variation Statistics to capture flows and the Population Register to capture population exposure.

The information on the movements and personal characteristics of migrants was obtained from the Residential Variation Statistics. The figures for the 19 Spanish regions ${ }^{10}$ are based on the estimations carried out by the National Statistics Office using the Spanish Labour Force Survey, Population Register, and Regional Account Statistics. Regarding the definition adopted here for internal migration, it is important to bear in mind that we are discussing the movement between major administrative

\footnotetext{
${ }^{10}$ Andalusia, Catalonia, Community of Madrid, Valencian Community, Galicia, Castile and Léon, Basque Country, Castile-La Mancha, Canary Islands, Region of Murcia, Aragon, Extremadura, Balearic Islands, Asturias, Navarre, Cantabria, La Rioja, Ceuta, and Melilla.
} 
geographic areas - that is, autonomous communities (hereafter referred to as "regions") - and are excluding from the analysis the changes that occurred within regions. ${ }^{11}$ This decision was made in response to the availability of published estimations on regional (rather than provincial) unemployment and activity rates, which were included as controls for the context of country of origin in the multivariate analysis. Additionally, as previously mentioned, this selection is also justified because Spanish interregional migration is driven more by economic determinants than by residential preferences and the former matter the most in an analysis such as the one conducted in this paper.

The following tables show the main characteristics of the data used for independent variables included in the multinomial regressions. The first focuses on individual characteristics and provides the trends by type of migration and period (Table 1). The second depicts the main trends for socioeconomic variables concerning the regions from which internal or international migrants departed between 2006 and 2013 (Table 2).

While all forms of international emigration show a relatively stable composition by sex throughout the three periods considered in the analysis, the share of foreign-born females who experienced internal migration increased significantly (Table 1). The mean age at migration systematically increased for internal migration, return migration, emigration to other EU countries, and emigration to an unknown destination, but no significant change was observed for the mean age at emigration to non-EU countries. Among those who experienced emigration to an unknown destination, there are no records for Spanish citizens because this category is derived from the enforcement of listing updates in the Population Register, which applies only to non-Spanish citizens.

${ }^{11}$ Inter- and intraprovince migration of foreign-born individuals has already been discussed by QuinteroLesmes (2016) and Recaño (2016). 
Prieto-Rosas, Recaño \& Quintero-Lesmes: Migration responses of immigrants during the Great Recession

Table 1: Individual sociodemographic characteristics by type of migration and period (annual averages, all foreign-born)

\begin{tabular}{|c|c|c|c|c|c|c|}
\hline & \multicolumn{3}{|c|}{ Interregional } & \multicolumn{3}{|l|}{ Return } \\
\hline & 2006-2008 & 2009-2010 & 2011-2013 & 2006-2008 & 2009-2010 & 2011-2013 \\
\hline \multicolumn{7}{|l|}{ Sex (percentage) } \\
\hline Male & 58.5 & 56.7 & 54.9 & 55.7 & 55.6 & 54.5 \\
\hline Female & 41.5 & 43.3 & 45.1 & 44.3 & 44.4 & 45.5 \\
\hline Total & 100.0 & 100.0 & 100.0 & 100.0 & 100.0 & 100.0 \\
\hline $\mathrm{N}$ & 199,766 & 185,399 & 161,760 & 30,179 & 40,086 & 49,696 \\
\hline \multicolumn{7}{|l|}{ Age } \\
\hline Mean & 31.1 & 31.9 & 33.2 & 32.6 & 33.8 & 35.7 \\
\hline S.E. & 0.0 & 0.0 & 0.0 & 0.1 & 0.1 & 0.0 \\
\hline \multicolumn{7}{|c|}{ Citizenship (percentage) } \\
\hline Non-EU28 & 70.9 & 71.1 & 65.7 & 50.1 & 48.6 & 44.9 \\
\hline EU28 & 19.9 & 16.9 & 17.8 & 37.3 & 34.7 & 29.9 \\
\hline Spain & 9.2 & 12.0 & 16.5 & 12.7 & 16.6 & 25.2 \\
\hline Total & 100.0 & 100.0 & 100.0 & 100.0 & 100.0 & 100.0 \\
\hline $\mathrm{N}$ & 199,766 & 185,399 & 161,760 & 30,179 & 40,086 & 49,696 \\
\hline \multicolumn{7}{|c|}{ Birthplace (percentage) } \\
\hline Europe $^{\star}$ & 23.4 & 20.3 & 21.8 & 45.4 & 42.0 & 36.4 \\
\hline Africa & 25.9 & 26.5 & 25.4 & 10.4 & 10.5 & 8.3 \\
\hline Asia \& Pacific Islands & 8.8 & 10.7 & 13.2 & 3.6 & 3.4 & 3.1 \\
\hline Latin America** & 41.9 & 42.5 & 39.7 & 40.6 & 44.1 & 52.2 \\
\hline Total & 100.0 & 100.0 & 100.0 & 100.0 & 100.0 & 100.0 \\
\hline $\mathrm{N}$ & 199,766 & 185,399 & 161,760 & 30,179 & 40,086 & 49,696 \\
\hline \multicolumn{7}{|c|}{ Main Latin American origins (percentage) } \\
\hline Cuba & 3.5 & 4.2 & 6.0 & 2.4 & 3.8 & 2.5 \\
\hline Dominican Republic & 5.0 & 6.8 & 9.3 & 3.1 & 3.3 & 3.0 \\
\hline Argentina & 10.2 & 8.9 & 8.7 & 14.9 & 13.2 & 9.1 \\
\hline Bolivia & 13.5 & 10.0 & 7.8 & 18.5 & 14.8 & 8.6 \\
\hline Brazil & 6.2 & 6.3 & 5.6 & 11.0 & 8.4 & 6.1 \\
\hline Colombia & 20.8 & 22.4 & 21.8 & 8.9 & 10.0 & 12.1 \\
\hline Ecuador & 19.3 & 16.7 & 14.6 & 8.7 & 14.8 & 29.2 \\
\hline Paraguay & 3.3 & 4.3 & 4.1 & 5.4 & 4.2 & 3.8 \\
\hline Peru & 5.8 & 7.1 & 6.4 & 4.3 & 5.1 & 6.7 \\
\hline Uruguay & 3.4 & 2.8 & 2.7 & 3.8 & 4.3 & 3.1 \\
\hline Venezuela & 4.7 & 5.3 & 6.5 & 8.1 & 8.4 & 7.3 \\
\hline Others ${ }^{\star * *}$ & 4.4 & 5.2 & 6.5 & 10.7 & 9.7 & 8.4 \\
\hline Total & 100.0 & 100.0 & 100.0 & 100.0 & 100.0 & 100.0 \\
\hline $\mathrm{N}$ & 83,718 & 78,793 & 64,230 & 12,243 & 17,671 & 25,952 \\
\hline
\end{tabular}


Table 1: (Continued)

\begin{tabular}{|c|c|c|c|c|c|c|c|c|c|}
\hline & \multicolumn{3}{|c|}{ Emigration to EU28 } & \multicolumn{3}{|c|}{ Emigration to non-EU28 } & \multicolumn{3}{|c|}{ Emigration to unknown dest. } \\
\hline & $\begin{array}{l}2006- \\
2008\end{array}$ & $\begin{array}{l}2009- \\
2010\end{array}$ & $\begin{array}{l}2011- \\
2013\end{array}$ & $\begin{array}{l}2006- \\
2008\end{array}$ & $\begin{array}{l}2009- \\
2010\end{array}$ & $\begin{array}{l}2011- \\
2013\end{array}$ & $\begin{array}{l}2006- \\
2008\end{array}$ & $\begin{array}{l}2009- \\
2010\end{array}$ & $\begin{array}{l}2011- \\
2013\end{array}$ \\
\hline \multicolumn{10}{|l|}{ Sex (percentage) } \\
\hline Male & 55.6 & 55.7 & 55.6 & 52.1 & 50.5 & 51.2 & 59.9 & 59.8 & 58.3 \\
\hline Female & 44.4 & 44.3 & 44.4 & 47.9 & 49.5 & 48.8 & 40.1 & 40.2 & 41.7 \\
\hline Total & 100.0 & 100.0 & 100.0 & 100.0 & 100.0 & 100.0 & 100.0 & 100.0 & 100.0 \\
\hline $\mathrm{N}$ & 3,133 & 4,675 & 7,447 & 2,038 & 2,598 & 3,950 & 149,071 & 264,873 & 284,061 \\
\hline \multicolumn{10}{|l|}{ Age } \\
\hline Mean & 33.3 & 34.3 & 35.2 & 35.1 & 35.2 & 35.6 & 33.3 & 34.1 & 35.6 \\
\hline S.E. & 0.1 & 0.1 & 0.1 & 0.2 & 0.2 & 0.1 & 0.0 & 0.0 & 0.0 \\
\hline \multicolumn{10}{|c|}{ Citizenship (percentage) } \\
\hline Non-EU28 & 35.8 & 30.7 & 20.1 & 29.7 & 27.7 & 22.2 & 88.5 & 73.4 & 65.6 \\
\hline EU28 & 25.3 & 24.0 & 18.4 & 18.3 & 17.0 & 13.7 & 11.5 & 26.6 & 34.4 \\
\hline Spain & 38.9 & 45.3 & 61.5 & 52.0 & 55.3 & 64.1 & $\mathrm{~N} / \mathrm{A}$ & $\mathrm{N} / \mathrm{A}$ & $\mathrm{N} / \mathrm{A}$ \\
\hline Total & 100.0 & 100.0 & 100.0 & 100.0 & 100.0 & 100.0 & 100.0 & 100.0 & 100.0 \\
\hline N & 3,133 & 4,675 & 7,447 & 2,038 & 2,598 & 3,950 & 149,071 & 264,873 & 284,061 \\
\hline \multicolumn{10}{|c|}{ Birthplace (percentage) } \\
\hline Europe $^{*}$ & 26.3 & 22.1 & 18.8 & 33.2 & 31.0 & 26.0 & 17.2 & 30.3 & 37.3 \\
\hline Africa & 28.0 & 33.6 & 35.1 & 8.0 & 7.6 & 6.4 & 24.9 & 19.0 & 17.9 \\
\hline Asia \& Pacific Islands & 9.6 & 7.9 & 6.5 & 7.6 & 6.6 & 6.2 & 12.1 & 9.2 & 9.6 \\
\hline Latin America* & 36.0 & 36.4 & 39.6 & 51.2 & 54.7 & 61.4 & 45.8 & 41.5 & 35.2 \\
\hline Total & 100.0 & 100.0 & 100.0 & 100.0 & 100.0 & 100.0 & 100.0 & 100.0 & 100.0 \\
\hline$N$ & 3,133 & 4,675 & 7,447 & 2,038 & 2,598 & 3,950 & 149,071 & 264,873 & 284,061 \\
\hline \multicolumn{10}{|c|}{ Main Latin American origins (percentage) } \\
\hline Cuba & 3.7 & 3.2 & 3.9 & 20.1 & 16.4 & 14.6 & 2.2 & 2.0 & 2.1 \\
\hline Dominican Republic & 5.8 & 6.1 & 6.4 & 5.8 & 6.7 & 6.9 & 3.6 & 3.1 & 3.7 \\
\hline Argentina & 16.0 & 12.6 & 9.7 & 10.9 & 12.2 & 9.4 & 12.3 & 11.1 & 10.0 \\
\hline Bolivia & 2.9 & 2.0 & 2.2 & 4.2 & 4.7 & 2.8 & 14.0 & 15.6 & 13.2 \\
\hline Brazil & 11.8 & 10.5 & 6.1 & 4.1 & 4.1 & 3.6 & 10.5 & 14.7 & 12.3 \\
\hline Colombia & 14.9 & 18.6 & 23.7 & 9.8 & 10.1 & 13.9 & 12.2 & 11.0 & 12.1 \\
\hline Ecuador & 11.9 & 13.7 & 19.1 & 6.2 & 6.6 & 14.8 & 17.5 & 12.7 & 13.0 \\
\hline Paraguay & 1.6 & 0.4 & 0.5 & 2.1 & 2.4 & 1.5 & 4.0 & 6.0 & 8.2 \\
\hline Peru & 9.3 & 9.9 & 9.2 & 7.7 & 6.9 & 6.3 & 6.0 & 6.1 & 7.0 \\
\hline Uruguay & 2.6 & 2.5 & 2.2 & 4.2 & 4.0 & 3.1 & 3.1 & 3.1 & 2.9 \\
\hline Venezuela & 9.3 & 10.8 & 9.3 & 13.4 & 14.7 & 12.6 & 4.0 & 3.8 & 4.3 \\
\hline Other ${ }^{* * *}$ & 10.4 & 9.6 & 7.6 & 11.4 & 11.1 & 10.5 & 10.8 & 10.5 & 11.2 \\
\hline Total & 100.0 & 100.0 & 100.0 & 100.0 & 100.0 & 100.0 & 100.0 & 100.0 & 100.0 \\
\hline $\mathrm{N}$ & 1,128 & 1,700 & 2,949 & 1,043 & 1,422 & 2,426 & 68,252 & 109,814 & 99,877 \\
\hline
\end{tabular}

Source: Own elaboration based on Spanish Residential Variation Statistics, 2006-2013 (National Statistics Office).

Notes: The values depicted here represent the annual average for each of the periods. * Europe includes both EU and non-EU countries. ** We have defined Latin America as South America, Central America, and the two Caribbean countries with significant participation in immigration in Spain, Cuba and the Dominican Republic. ${ }^{* *}$ Others include Mexico, Costa Rica, El Salvador, Guatemala, Honduras, Nicaragua, Panama, Chile, Guyana and Surinam. 
Prieto-Rosas, Recaño \& Quintero-Lesmes: Migration responses of immigrants during the Great Recession

Table 2: Contextual sociodemographic characteristics by autonomous community of origin for internal migration and international emigration and period (all foreign-born)

\begin{tabular}{|c|c|c|c|c|c|c|c|c|c|c|c|c|}
\hline & \multicolumn{12}{|c|}{ Unemployment rate (percentage) } \\
\hline & \multicolumn{6}{|c|}{ Spanish citizens } & \multicolumn{6}{|c|}{ Non-EU28 } \\
\hline & \multicolumn{3}{|c|}{ Male } & \multicolumn{3}{|l|}{ Female } & \multicolumn{3}{|c|}{ Male } & \multicolumn{3}{|l|}{ Female } \\
\hline & $\begin{array}{l}2006- \\
2008\end{array}$ & $\begin{array}{l}2009- \\
2010\end{array}$ & $\begin{array}{l}2011- \\
2013\end{array}$ & $\begin{array}{l}2006- \\
2008\end{array}$ & $\begin{array}{l}2009- \\
2010\end{array}$ & $\begin{array}{l}2011- \\
2013\end{array}$ & $\begin{array}{l}2006- \\
2008\end{array}$ & $\begin{array}{l}2009- \\
2010\end{array}$ & $\begin{array}{l}2011- \\
2013\end{array}$ & $\begin{array}{l}2006- \\
2008\end{array}$ & $\begin{array}{l}2009- \\
2010\end{array}$ & $\begin{array}{l}2011- \\
2013\end{array}$ \\
\hline Andalusia & 10.3 & 24.2 & 30.9 & 17.7 & 32.6 & 33.6 & 11.6 & 38.9 & 44.2 & 18.9 & 31.5 & 38.8 \\
\hline Aragon & 3.3 & 10.2 & 14.8 & 7.5 & 12.4 & 17.6 & 15.5 & 33.7 & 39.6 & 9.6 & 23.3 & 39.5 \\
\hline Asturias & 6.2 & 13.8 & 20.0 & 10.6 & 15.6 & 19.4 & 9.6 & 30.5 & 42.5 & 12.1 & 26.1 & 32.4 \\
\hline Balearic Islands & 5.0 & 14.8 & 19.0 & 7.5 & 14.6 & 19.3 & 8.6 & 38.0 & 28.0 & 10.2 & 29.4 & 29.5 \\
\hline Canary Islands & 10.0 & 25.0 & 31.0 & 14.5 & 26.8 & 31.0 & 12.1 & 40.9 & 36.1 & 17.1 & 33.6 & 32.1 \\
\hline Cantabria & 4.2 & 11.0 & 17.3 & 8.9 & 12.8 & 16.4 & 11.2 & 14.3 & 42.3 & 14.9 & 25.3 & 26.8 \\
\hline Castile-La Mancha & 5.4 & 15.9 & 22.9 & 12.7 & 20.5 & 28.8 & 13.5 & 41.8 & 44.3 & 19.3 & 39.5 & 44.5 \\
\hline Castile and Léon & 5.0 & 12.0 & 15.0 & 10.0 & 16.2 & 19.7 & 14.6 & 22.0 & 35.3 & 20.2 & 30.6 & 35.7 \\
\hline Catalonia & 5.0 & 14.0 & 18.1 & 6.1 & 13.8 & 17.4 & 12.8 & 35.2 & 43.4 & 14.8 & 25.9 & 36.2 \\
\hline Ceuta & 15.8 & 15.8 & 26.4 & 28.4 & 24.4 & 39.6 & 19.0 & 44.2 & 47.5 & 39.8 & 60.0 & 58.0 \\
\hline Extremadura & 9.4 & 16.6 & 27.3 & 18.9 & 25.2 & 32.2 & 12.0 & 37.1 & 59.5 & 16.8 & 22.6 & 46.1 \\
\hline Galicia & 5.7 & 13.0 & 19.3 & 10.5 & 14.2 & 19.0 & 11.6 & 20.5 & 35.6 & 14.3 & 20.9 & 34.8 \\
\hline Madrid & 5.1 & 12.0 & 15.3 & 7.7 & 14.2 & 16.8 & 12.4 & 28.8 & 33.2 & 12.3 & 17.5 & 23.9 \\
\hline Melilla & 14.0 & 18.6 & 24.0 & 24.6 & 23.5 & 25.2 & 16.0 & 37.0 & 37.3 & 64.6 & 82.0 & 57.4 \\
\hline Murcia & 6.0 & 17.0 & 24.7 & 10.0 & 18.2 & 24.6 & 11.7 & 32.8 & 34.3 & 12.5 & 24.4 & 32.6 \\
\hline Navarra & 3.4 & 8.3 & 13.5 & 6.3 & 10.5 & 11.9 & 10.9 & 32.0 & 42.0 & 11.4 & 24.8 & 44.2 \\
\hline Basque Country & 4.5 & 9.5 & 12.5 & 7.3 & 10.1 & 13.2 & 21.0 & 22.8 & 37.0 & 12.6 & 21.6 & 29.8 \\
\hline Rioja & 3.0 & 9.1 & 16.0 & 5.9 & 9.9 & 16.0 & 14.9 & 31.0 & 39.6 & 19.8 & 34.0 & 35.4 \\
\hline Valencia & 7.0 & 18.0 & 23.4 & 10.3 & 20.3 & 24.7 & 14.0 & 39.4 & 41.0 & 18.6 & 30.3 & 35.2 \\
\hline Spain & 6.8 & 14.7 & 20.6 & 11.9 & 17.7 & 22.4 & 13.3 & 32.7 & 40.1 & 18.9 & 31.8 & 37.5 \\
\hline
\end{tabular}


Table 2: (Continued)

\begin{tabular}{|c|c|c|c|c|c|c|c|c|c|}
\hline & \multicolumn{3}{|c|}{$\begin{array}{l}\text { Log. of Latin American } \\
\text { population }\end{array}$} & \multicolumn{3}{|c|}{ GDP per capita } & \multicolumn{3}{|c|}{ Hourly wage (euros) } \\
\hline & $\begin{array}{l}2006- \\
2008\end{array}$ & $\begin{array}{l}2009- \\
2010\end{array}$ & $\begin{array}{l}2011- \\
2013\end{array}$ & $\begin{array}{l}2006- \\
2008\end{array}$ & $\begin{array}{l}2009- \\
2010\end{array}$ & $\begin{array}{l}2011- \\
2013\end{array}$ & $\begin{array}{l}2006- \\
2008\end{array}$ & $\begin{array}{l}2009- \\
2010\end{array}$ & $\begin{array}{l}2011- \\
2013\end{array}$ \\
\hline Andalusia & 2.0 & 2.2 & 2.2 & 18.2 & 17.7 & 16.8 & 15.6 & 17.2 & 17.4 \\
\hline Aragon & 3.0 & 3.6 & 3.7 & 25.8 & 25.5 & 24.7 & 17.3 & 18.9 & 19.0 \\
\hline Asturias & 2.5 & 3.2 & 3.3 & 21.5 & 21.2 & 20.1 & 17.7 & 19.4 & 19.6 \\
\hline Balearic Islands & 7.6 & 8.5 & 8.4 & 25.3 & 24.2 & 23.5 & 16.0 & 17.6 & 18.1 \\
\hline Canary Islands & 6.9 & 7.6 & 7.7 & 20.9 & 20.0 & 19.3 & 15.6 & 17.3 & 17.4 \\
\hline Cantabria & 3.0 & 4.0 & 4.1 & 22.2 & 21.8 & 20.6 & 16.8 & 18.4 & 18.7 \\
\hline Castile-La Mancha & 2.7 & 3.4 & 3.3 & 19.1 & 18.8 & 18.0 & 15.4 & 17.5 & 17.5 \\
\hline Castile and Léon & 2.1 & 2.6 & 2.6 & 21.8 & 21.8 & 21.2 & 16.4 & 18.0 & 18.1 \\
\hline Catalonia & 6.0 & 6.8 & 6.8 & 27.8 & 27.2 & 26.3 & 18.3 & 20.1 & 20.3 \\
\hline Ceuta & 0.3 & 0.4 & 0.5 & 20.2 & 19.9 & 18.7 & 18.2 & 20.0 & 20.0 \\
\hline Extremadura & 0.8 & 1.1 & 1.1 & 15.9 & 16.3 & 15.5 & 14.6 & 16.5 & 16.9 \\
\hline Galicia & 3.2 & 3.7 & 3.8 & 20.3 & 20.5 & 19.8 & 15.4 & 17.1 & 17.3 \\
\hline Madrid & 8.5 & 9.7 & 9.4 & 31.3 & 31.2 & 30.7 & 19.5 & 21.4 & 21.7 \\
\hline Melilla & 0.3 & 0.6 & 0.7 & 19.4 & 18.6 & 17.1 & 18.0 & 19.7 & 19.6 \\
\hline Murcia & 6.0 & 6.0 & 5.7 & 19.7 & 19.2 & 18.4 & 14.8 & 16.4 & 16.3 \\
\hline Navarra & 5.4 & 6.3 & 6.3 & 29.3 & 28.8 & 27.8 & 19.1 & 21.0 & 21.0 \\
\hline Basque Country & 2.7 & 3.6 & 3.8 & 30.0 & 30.0 & 29.3 & 20.4 & 22.1 & 22.3 \\
\hline Rioja & 4.2 & 4.7 & 4.6 & 25.3 & 25.0 & 24.2 & 16.8 & 18.3 & 18.3 \\
\hline Valencia & 4.6 & 4.8 & 4.6 & 21.4 & 20.6 & 19.6 & 15.9 & 17.8 & 17.8 \\
\hline Spain & 4.5 & 5.1 & 5.1 & 22.9 & 22.5 & 21.7 & 16.9 & 18.7 & 18.8 \\
\hline
\end{tabular}

Source: Own elaboration based on Spanish Labour Force Survey, 2006-2013, Spanish Population Register, 2006-2013, and Spanish Regional Accounts Statistics (National Statistics Office).

Note: All rates depict an annualized value for the period under study.

Since Latin Americans form the largest group of foreign-born immigrants in Spain, it is natural to find that they are also the largest group within the five types of movement being studied. However, the share of Latin Americans within internal migrants decreased after the crisis (Recaño 2016), and very recently (2011-2013) Europeans became the majority group for emigration to an unknown destination.

Most people with Latin American countries of origin have decreased their participation in internal migration, except for Colombians, Cubans, Dominicans, and Venezuelans. Colombians and Ecuadorians are also among those to show a significant increase in the share of returnees and, together with Dominicans and Africans, they led the foreign-born emigration to other EU countries. Obviously, those from the most populous countries of origin within the Latin American immigrant population led the increase in return migration to EU and non-EU destinations, but significant changes occurred over the period of analysis regarding the relative composition of international emigration by country of origin.

The multinomial regression presented in the following section includes individual as well as contextual characteristics for the autonomous communities of origin 
(regions), such as unemployment and activity rates by sex and birthplace (EU28 and non-EU28 countries), total population activity rate by economic sector and sex (services, construction, manufacturing, and agriculture), hourly wage, and Latin American population. In Table 2, we depict the main trends of these variables by Spanish region.

Unemployment rates among the foreign-born population have shown a substantial increase for all individuals, including Spanish citizens and non-EU citizens. The national averages included in Table 2 indicate that the unemployment rate of both sexes went from approximately $10 \%$ to $21 \%$ among Spanish citizens, and from $16 \%$ to almost $40 \%$ among non-EU citizens. In most of the regions, the slope of the growth has been significantly larger for non-EU citizens and males. In fact, among Spanish citizens the crisis led to convergence between both sexes within each citizenship group. Male unemployment among Spanish citizens was significantly low before the crisis, but due to its direct impact on construction the unemployment rate of Spanish males caught up with that of Spanish females. Similarly, the increase in male unemployment rates for non-EU citizens was so marked that at the end of the period 2011-2013 it surpassed the unemployment rates for females in the same group.

Nevertheless, the geography of unemployment did not change much before and after the crisis. The regions that continued to have higher unemployment rates for both sexes and citizenship groups included Andalusia, Castile-La Mancha, Valencia, and Ceuta and Melilla. The regions that joined this group only after the crisis were Asturias, Cantabria, Catalonia, Extremadura, and Murcia. We would expect to find a positive relationship between unemployment rates and international emigration.

Despite the decline in the foreign immigration flow, the share of Latin Americans in the total population continued to grow, though at a slower rate, during the period of study. The regions with the larger Latin American populations continued to be Catalonia, Madrid, Valencia, the Canary Islands, Murcia, Galicia, Castile-La Mancha, Castile and Léon, and the Balearic Islands. These were also the regions where foreign immigration was well established and the size of the Latin American community might have prevented international emigration and instead supported internal inflows of those in search of economic and emotional support from relatives during the crisis.

Except for Madrid and Extremadura, the GDP per capita decreased in all the Spanish regions. Judging by the trends depicted by GDP per capita and hourly wage, the geography of the richest and poorest regions did not change much during the crisis. The first group of regions was led by Madrid, the Basque Country, Navarra, Catalonia, Aragon, Valencia, and the Balearic Islands. However, the last four regions suffered a relative decline in GDP per capita, which particularly affected Catalonia and the Balearic Islands. Therefore, even though these are not typically regions that people leave, but rather the opposite, the impact of the crisis hit their economies due to their 
strong links with services and construction, and any form of outflow could be expected. This is particularly true if we also consider that they are the regions with the largest number of foreign-born individuals, which means they have more exposure to return migration and remigration in a context of economic recession.

\section{Results}

\subsection{Transformations in the intensity of internal and international migration of immigrants}

The evidence presented next shows that the responses of all groups to the crisis involved the contraction of interregional migration propensities (Table 3). Bearing in mind that this analysis excludes most of the internal mobility that occurs within the same regions, which accounts for more than two-thirds of the total internal movements in Spain, we note that although the reduction of interregional migration affected both Spanish and foreign-born populations, the magnitude of the decline was significantly greater among the latter (Table 3).

There are at least two interpretations of these findings. On the one hand, members of the Spanish-born population, who could have considerable social networks in different regions of the country, might have sought employment opportunities in other areas because they felt more confident about migrating than foreign immigrants. In fact, one of the results of the crisis was the return of natives from the southern regions of Spain to seasonal work in agriculture: collecting olives or working in a traditional position that had been taken in previous periods by those born abroad. On the other hand, the greater reduction in foreign-born internal migration could reflect a conservative strategy of remaining within a known area, though in the territorial units that contain metropolitan areas it could also imply a diversification of job hunting within the borders of the same region. Internal migration in many cases preceded international emigration during the recession. After the crisis broke out, immigrants sought employment in Madrid and Catalonia, the regions with the greatest economic opportunities and most diversified economies, where the impact of the crisis, although high, was less than in areas dependent on sectors such as construction (Recaño 2016). These two regions, where a large part of the foreign-born population was concentrated, also represented geographical spaces of attraction for internal migration due to the effect of social networks (Recaño, Roig, and de Miguel 2015). 
Table 3: Interregional migration rates (per 1,000), international emigration rates, and international emigration growth index $(\%)$ by place of birth (Spain, 2006-2013)

\begin{tabular}{llllllllllllll}
\hline & \multicolumn{3}{l}{ Spanish } & \multicolumn{4}{c}{ Latin Americans } & \multicolumn{3}{c}{ Rest of foreign-born } & \multicolumn{2}{c}{ Total foreign-born } \\
\hline Period & I & IE & $\begin{array}{l}\text { Index IE } \\
(\%)\end{array}$ & I & IE & $\begin{array}{l}\text { Index IE } \\
(\%)\end{array}$ & I & IE & $\begin{array}{l}\text { Index IE } \\
(\%)\end{array}$ & I & IE & $\begin{array}{l}\text { Index IE } \\
(\%)\end{array}$ \\
\hline $2006-2008$ & 8.9 & 0.7 & $100 \%$ & 38.7 & 38.2 & $100 \%$ & 33.3 & 29.2 & $100 \%$ & 35.4 & 32.6 & $100 \%$ \\
$2009-2010$ & 8.5 & 0.9 & $132 \%$ & 32.2 & 53.3 & $139 \%$ & 25.8 & 43.9 & $150 \%$ & 28.1 & 47.4 & $145 \%$ \\
$2011-2013$ & 8.6 & 1.4 & $198 \%$ & 26.5 & 54.1 & $142 \%$ & 23.2 & 50.9 & $174 \%$ & 24.4 & 52.1 & $160 \%$ \\
\hline
\end{tabular}

Source: Spanish Population Register and Residential Variation Statistics (National Statistics Office, 2006-2013).

Notes: I = interregional migration rate; $\mathrm{IE}=$ international emigration rate; Index IE = index of international emigration growth compared to value of international emigration rate for 2006-2008. All rates depict an annualized value for the period in study.

In contrast to what occurred with respect to interregional migration, international emigration from Spain has grown steadily among all groups, including natives, Latin Americans, and other foreign-born populations. In the last two groups, emigration from Spain has represented the dominant form of migration since the beginning of the crisis, ${ }^{12}$ when Latin Americans showed the larger emigration rates (2009-2010). At a later stage, this form of mobility kept growing at a lower rate and the intensity of Latin American interregional migration and international emigration converged with that of other foreign-born groups (Table 3).

In short, we found at least four remarkable transformations. First, a contraction of interregional migration was displayed by populations of all origins, although the intensities of the reduction were larger for the foreign-born than for the native populations. Second, there was a general expansion of departures from Spain. Third, despite the fact that Latin Americans led the first upsurge of emigration, emigration rates for other foreign-born groups converged in 2011-2013. Fourth, we observed a growth in the external mobility of Spanish people, although it remains a residual phenomenon concerning only $13 \%$ of all migration responses considered here (Table A-1 in the Appendix).

\footnotetext{
${ }^{12}$ Emigration from Spain represented more than $62.7 \%$ of the total migration among foreign-born individuals, whereas it accounted for only $9.6 \%$ of the total mobility among Spaniards in 2009-2010 (Table A-1 in the Appendix).
} 
Table 4: Annual migration flows and rates (per 1,000) by type of movement and place of birth (Spain, 2006-2013)

\begin{tabular}{|c|c|c|c|c|c|}
\hline Flows & $\begin{array}{l}\text { Latin Americans } \\
\text { Return migration }\end{array}$ & $\begin{array}{l}\text { Remigration to } \\
\text { EU28 }\end{array}$ & $\begin{array}{l}\text { Remigration to } \\
\text { non-EU28 }\end{array}$ & $\begin{array}{l}\text { Unknown } \\
\text { destination }\end{array}$ & Total \\
\hline $2006-2008$ & 10,410 & 981 & 934 & 56,463 & 68,788 \\
\hline 2009-2010 & 17,087 & 1,613 & 1,377 & 103,900 & 123,977 \\
\hline 2011-2013 & 25,958 & 2,955 & 2,432 & 99,955 & 131,300 \\
\hline \multicolumn{6}{|l|}{ Rates } \\
\hline $2006-2008$ & 4.8 & 0.5 & 0.4 & 26.1 & 31.8 \\
\hline $2009-2010$ & 7.0 & 0.7 & 0.6 & 42.4 & 50.6 \\
\hline $2011-2013$ & 10.7 & 1.2 & 1.0 & 41.2 & 54.1 \\
\hline Flows & $\begin{array}{l}\text { Rest of foreign-born } \\
\text { Return migration }\end{array}$ & $\begin{array}{l}\text { Remigration to } \\
\text { EU28 }\end{array}$ & $\begin{array}{l}\text { Remigration to } \\
\text { non-EU28 }\end{array}$ & $\begin{array}{l}\text { Unknown } \\
\text { destination }\end{array}$ & Total \\
\hline $2006-2008$ & 15,505 & 1,809 & 877 & 72,882 & 91,073 \\
\hline 2009-2010 & 22,540 & 2,781 & 1,151 & 135,523 & 161,994 \\
\hline 2011-2013 & 23,739 & 4,498 & 1,488 & 184,106 & 213,831 \\
\hline \multicolumn{6}{|l|}{ Rates } \\
\hline $2006-2008$ & 4.4 & 0.5 & 0.3 & 20.9 & 26.1 \\
\hline 2009-2010 & 5.4 & 0.7 & 0.3 & 32.8 & 39.2 \\
\hline 2011-2013 & 5.7 & 1.1 & 0.4 & 43.8 & 50.9 \\
\hline
\end{tabular}

Source: Spanish Population Register and Residential Variation Statistics (National Statistics Office, 2006-2013).

Note: All rates depict an annualized value for the period under study.

In Table 4, we analyse international emigration from Spain in its different forms: return migration, remigration to a known destination, and emigration to an unknown destination. In the general context of the growth of international emigration, emigration from Spain to an unknown destination was the predominant form among foreign-born individuals. However, the pattern was clearly different for Latin Americans than for other foreign-born immigrants. Whereas this type of outflow decreased from 2011 among Latin Americans, it continued growing for other immigrants of foreign origin. The second most common form of mobility among foreign-born people was international return. By 2011-2013, the return migration rate of Latin Americans had doubled from 2006-2008, and this growth was significantly lower for other populations of foreign origin. The third form of mobility corresponded to remigration. This was a growing phenomenon among the different groups considered in this study. Latin Americans and other foreigners exhibited similar propensities regarding remigration to EU28 countries but differed when the outflow was directed towards countries outside the EU28. In this case, Latin Americans migrated to both EU28 and non-EU28 countries at very similar rates, whereas the flow to non-EU28 countries was significantly lower among the rest of the foreign-born population. 


\subsection{Individual and contextual factors associated with interregional and international migration}

In accordance with the bivariate analysis, our findings from the multinomial regression point to the decline of interregional migration and the increase of emigration to unknown destinations as the greatest transformations over the period examined in this study (Figure 2). The former suffered a steep two-stage decline regardless of birthplace and was particularly pronounced for those with non-Spanish citizenship (Figure 2). The decline of interregional migration was accompanied by the growth of different forms of international emigration, but the preferred type of emigration varied by country of origin. For example, among Europeans and Latin Americans with Spanish citizenship, a larger increase in return migration was observed, while among Africans and Asians with Spanish citizenship, the largest transformation was observed for emigration to other EU and non-EU countries.

\section{Figure 2: $\quad$ Predicted probabilities of migration responses by birthplace and} citizenship (all foreign-born populations)
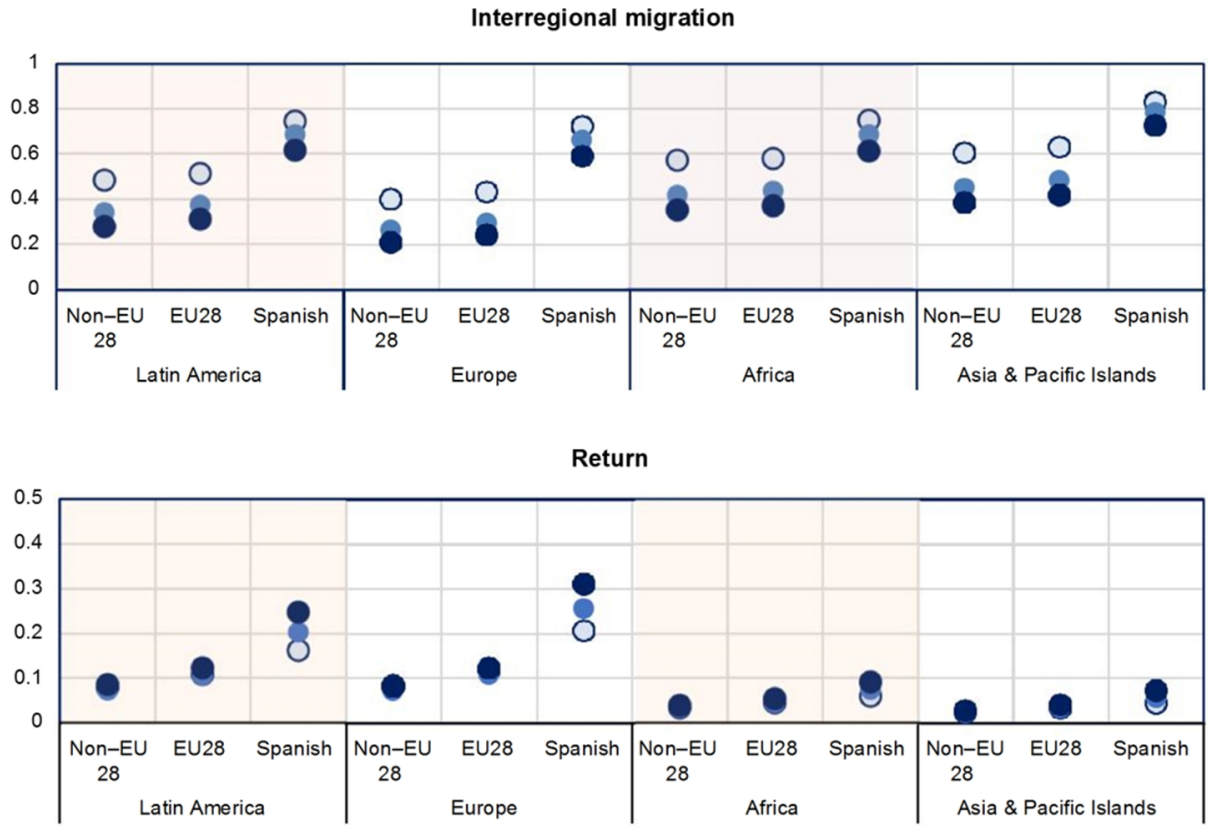
Figure 2: (Continued)

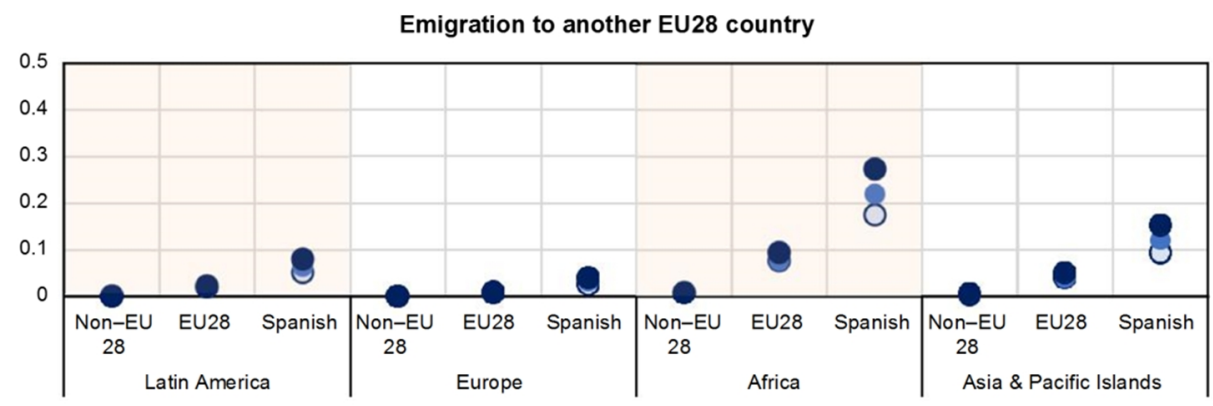

Emigration to a non-EU28 country

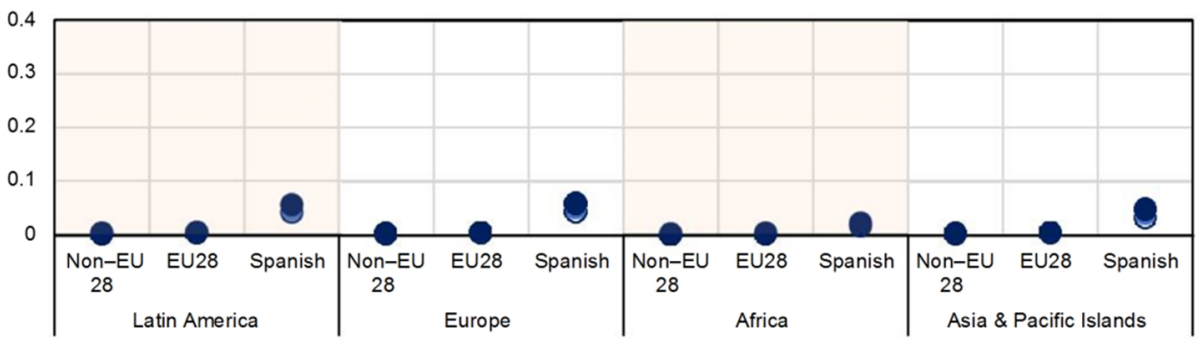

Emigration to an unknown destination

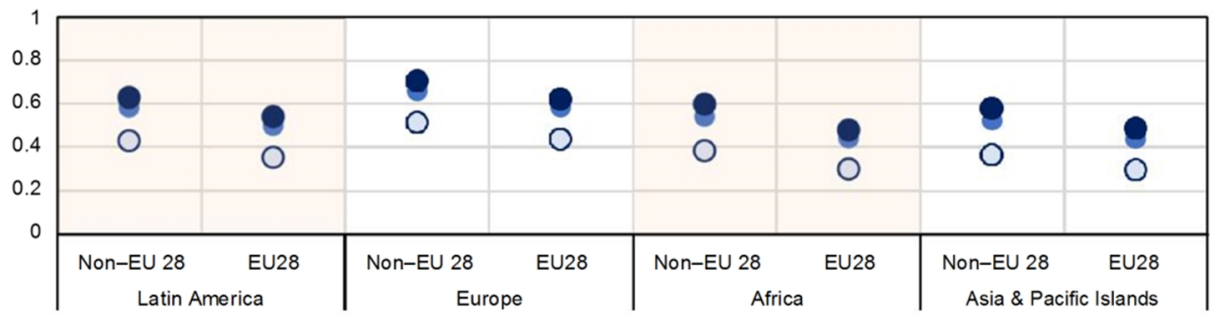

02006-2008 •2009-2010 •2011-2013

Source: Own elaboration based on estimates from multinomial regression for all foreign-born populations.

Latin Americans and Europeans stand out as groups for which the decline of interregional migration was also accompanied by a slight increase in emigration to nonEU destinations. Finally, while return migration and both forms of remigration (to known destinations) increased at a stable pace, emigration to an unknown destination rose in a two-stage pattern: a sharp increase at the onset of the crisis and then a minor increase during the recession (Figure 2). It could be that immigrants in worse conditions 
- that is, a shorter duration of residence - who had not become naturalized were the first to leave Spain or 'disappear' (relocate to an unknown destination). For example, an immigrant with several years' residence in Spain and Spanish citizenship would be more likely to have material and nonmaterial resources to withstand the first stages of the crisis. Meanwhile, a newcomer, with little time to aspire to naturalization, employed in the most vulnerable sectors of the economy, such as construction, would logically be more likely to leave Spain as soon as the crisis hit.

\section{Figure 3: $\quad$ Predicted probabilities of interregional migration by birthplace and} citizenship (Latin American immigrants)
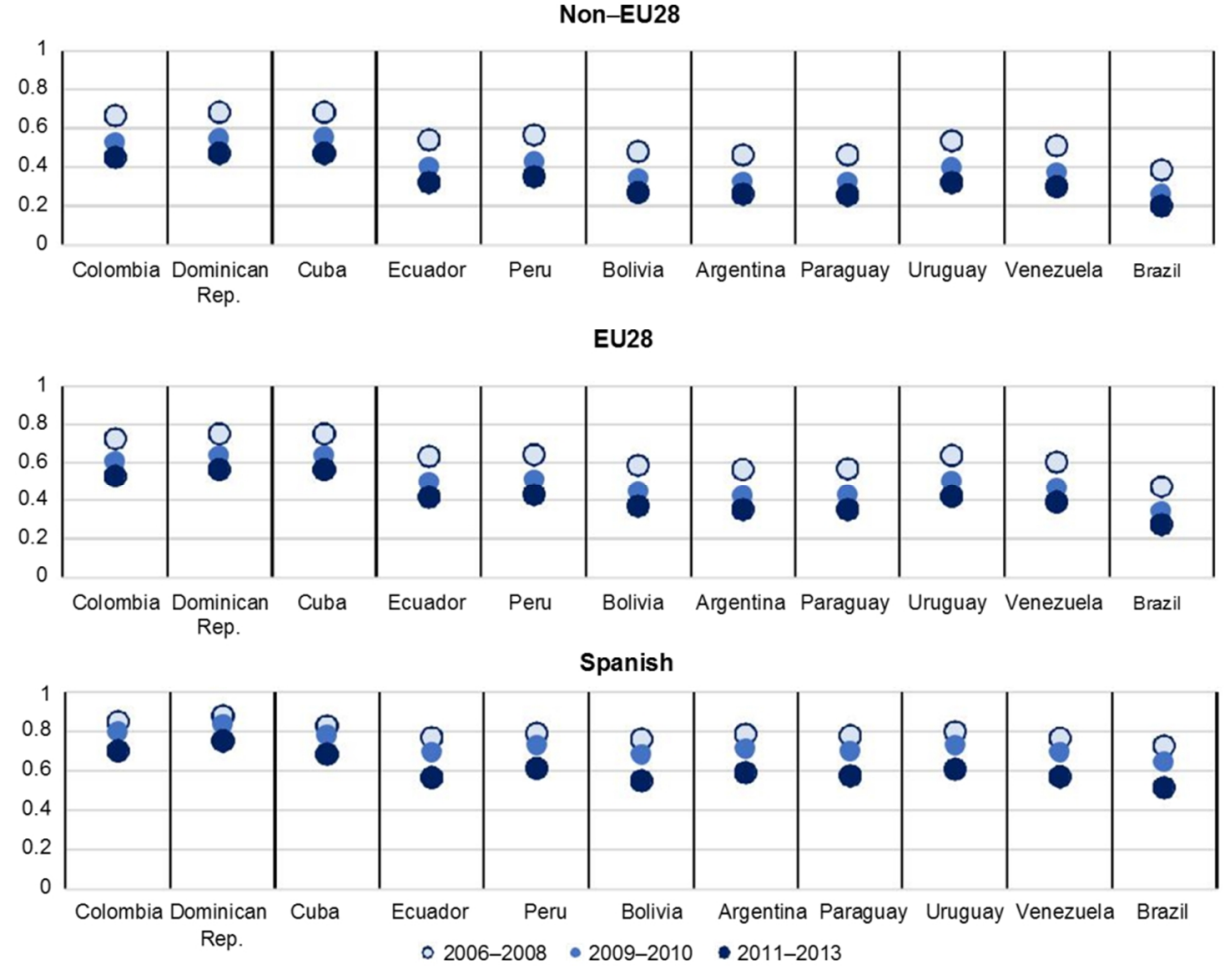

Source: Own elaboration based on estimates from multinomial regression for Latin American immigrants.

Focusing now on Latin Americans, the predicted probabilities derived from the models restricted to this group enable us to address differences by country of birth and citizenship. Again, the two migration responses for which we observed the largest 
transformation after the onset of the crisis correspond to interregional migration (Figure 3 ) and emigration to an unknown destination (Figure 4). The magnitude of the decline observed for interregional migration was very marked among the Latin Americans without Spanish citizenship, for whom the decline began as soon as the crisis started (2009-2010) (Figure 3). Conversely, the Latin Americans with Spanish citizenship suffered the sharpest decline during the recession (2011-2013), but kept relatively high probabilities of experiencing internal migration during the start of the crisis.

\section{Figure 4: Predicted probabilities of emigration from Spain to an unknown destination by birthplace and citizenship (Latin American immigrants)}

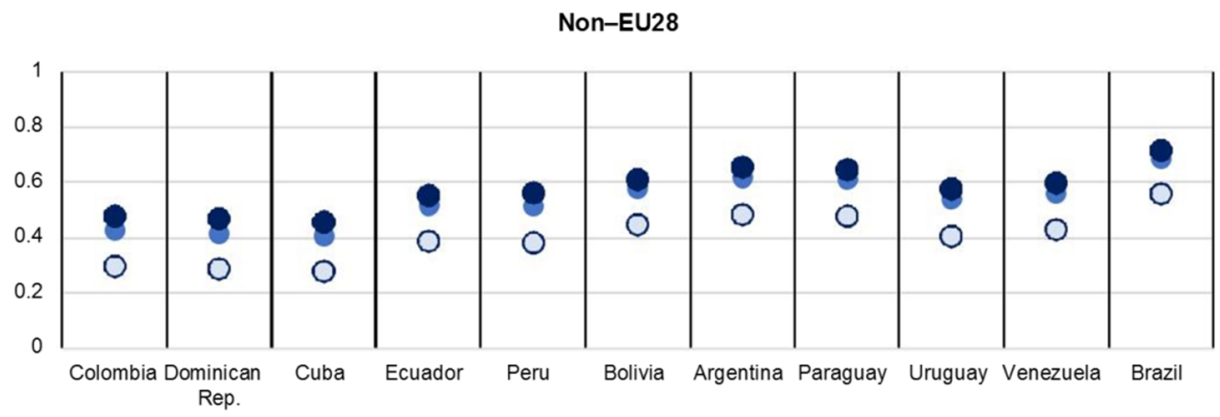

EU28

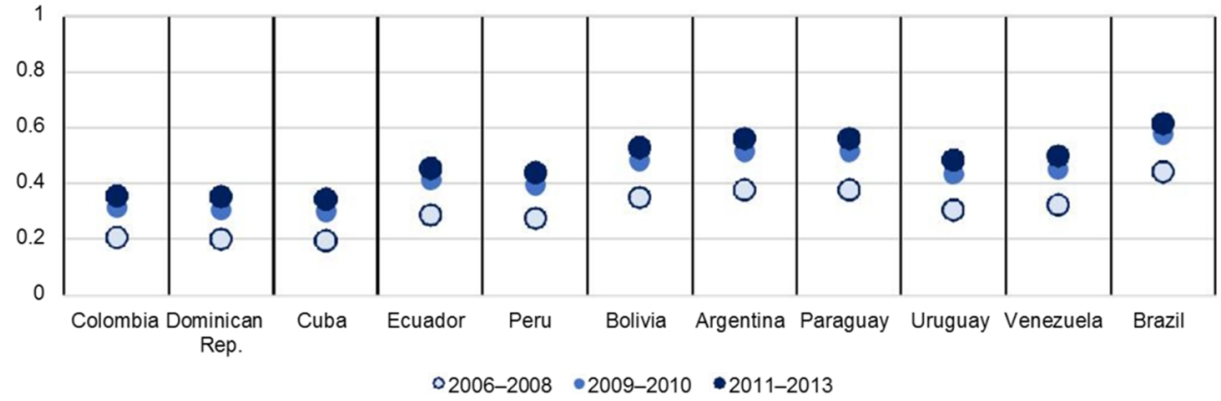

Source: Own elaboration based on estimates from multinomial regression for Latin American immigrants.

The predicted probabilities of emigration from Spain to an unknown destination depicted in Figure 4 show that all countries of origin experienced a sharp increase in this kind of emigration in 2009-2010: that is, immediately after the crisis started. Nevertheless, Cubans, Colombians, and Dominicans still showed the lowest odds of 
experiencing the latter type of mobility compared to Latin Americans from other countries of origin. The largest probability of experiencing this type of migration was found among Brazilians, Paraguayans, Argentinians, and Bolivians with non-EU citizenship. Predicted probabilities for other types of international emigration are shown in the Appendix (Figures A-1-A-3).

These findings indicate that the crisis affected those who had not acquired Spanish citizenship immediately (2008-2009) and those who were Spanish citizens (20112013). Halfway between these groups was the reaction of those who were more likely to have another European citizenship, such as Argentinians, Brazilians, Uruguayans, and Venezuelans. So we can argue that migration responses are incremental according to nationality, which is a proxy of social rights acquired (access to unemployment insurance or low-income subsidy), longer settlement time, and, therefore, a higher density of social networks.

To examine the effect of the sociodemographic and regional covariates included to predict the probabilities already shown, we will continue by examining marginal effects as depicted in Figures 5 and 6. The full tables with results are included in the Appendix (Tables A-2 and A-3).

According to the marginal effects obtained for the estimated models, males are, on average, more prone to return migration and emigration to an unknown destination than females, who have a larger probability of moving within Spanish regions and within the European Union (Figure 5). Nevertheless, the marginal effect of sex is not significant for predicting the probability of experiencing emigration to non-EU28 countries. This is also true among Latin American females (Figure 6).

On average, those aged 45 and over showed a higher probability of experiencing emigration to non-EU or unknown destinations than internal migration compared to younger age groups (16-29). The marginal effect for emigration to unknown destinations indicates that the probability of experiencing this type of migration increases by approximately $19 \%$ for the oldest age group in comparison to the youngest group among all foreign-born groups, and by about $22 \%$ when we consider only the Latin American immigrants. Conversely, the probability for internal migration decreases by approximately $24 \%$ for the oldest age group in comparison to the youngest among all foreign-born individuals, and this decrease is even stronger $(-27 \%)$ for Latin Americans at advanced ages (60+) (Tables A-2 and A-3 in the Appendix). 
Figure 5: Average marginal effects for all foreign-born populations by migration response

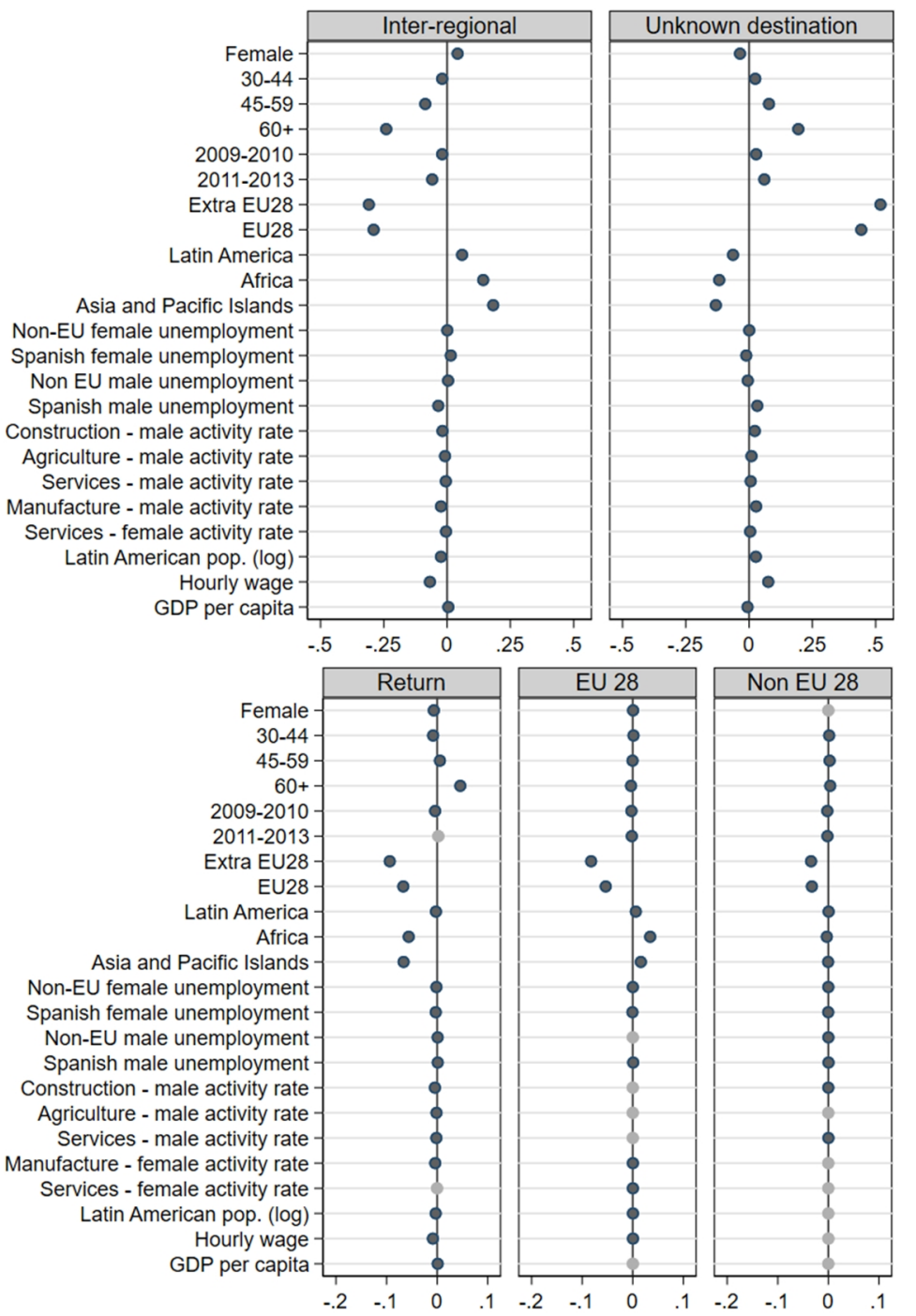

Source: Own elaboration based on estimates from the full model for all foreign-born populations (Model 2).

Notes: Confidence intervals are not visible due to the minuscule size of marginal effects' standard errors, which are available in Table A-2 in the Appendix. To distinguish nonsignificant marginal effects, we used pale grey colouring. 
Prieto-Rosas, Recaño \& Quintero-Lesmes: Migration responses of immigrants during the Great Recession

\section{Figure 6: $\quad$ Average marginal effects for Latin Americans by migration response}

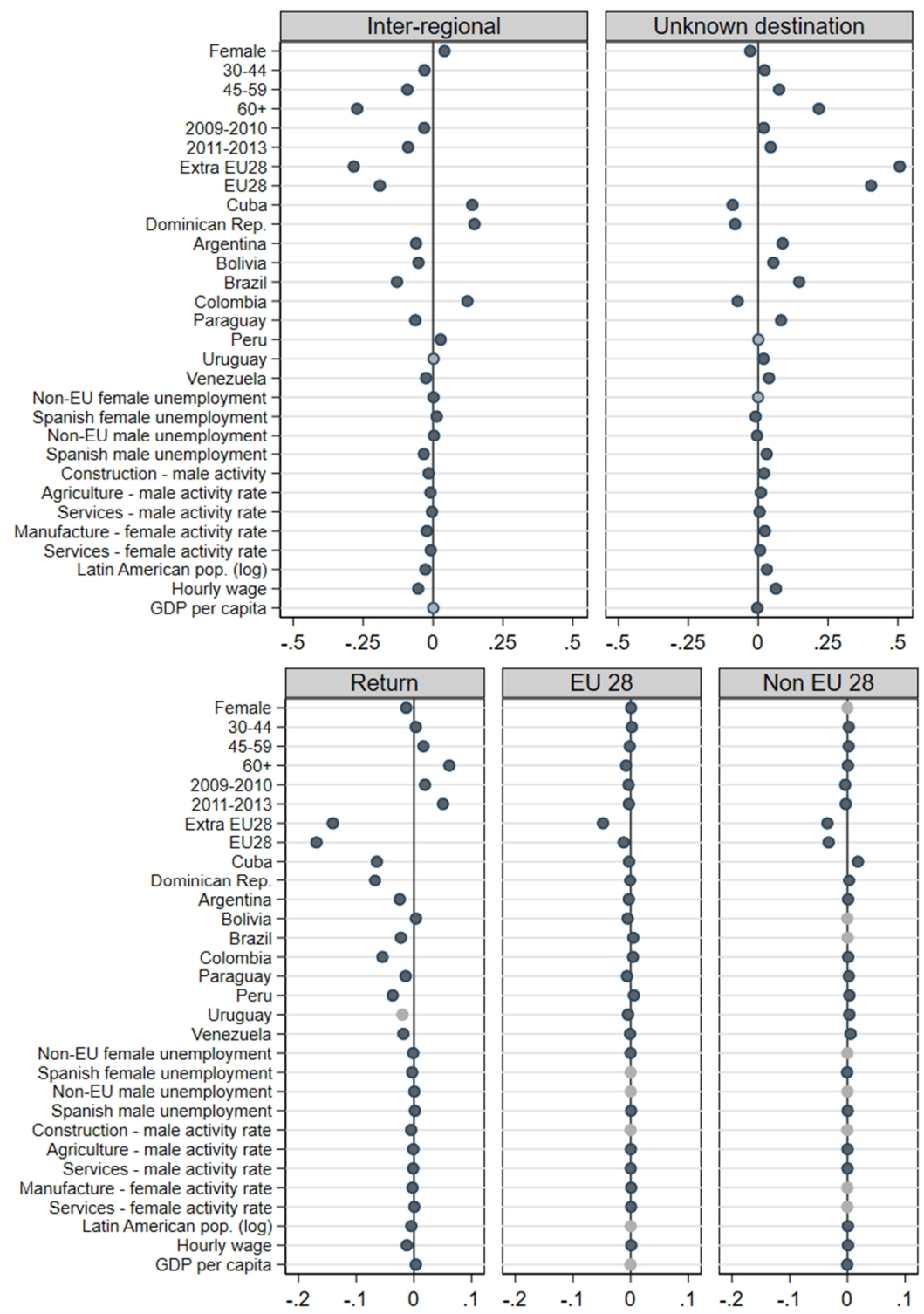

Source: Own elaboration based on estimates from the full model for all foreign-born populations.

Notes: Confidence intervals are not visible due to the minuscule size of marginal effects' standard errors, which are available in Table A-3 in the Appendix. To distinguish nonsignificant marginal effects, we used pale grey colouring. 
As expected, the probability of emigration to an unknown destination increased by about $2.8 \%$ in comparison to internal migration in 2009-2010, at the onset of the crisis, but the effect of the recession (2011-2013) was even larger (6.8\%) for all those who were foreign-born. Again, this is also true for Latin Americans (Figure A-3 in the Appendix). Thus, the multivariate analysis shows that once sex, age, citizenship, and birthplace are considered, the largest transformations experienced by the foreign-born population were the increase in emigration to an unknown destination and the decline of all other forms of migration, including interregional migration. Furthermore, among Latin Americans, both forms of transformation were observed, but for this group we should add a significant increase in the marginal effect of these periods on return migration (Figure 6). On the one hand, this result in the case of Latin Americans is explained by the different composition of the international emigration; those who went to an unknown destination were the less well-rooted immigrants, with shorter duration of residence in Spain, which we assume because they did not have Spanish nationality. On the other hand, the increase in return migration evolved in line with the deterioration of general economic conditions during the crisis. In the first phases, Latin American immigrants with Spanish nationality - who were presumably more likely to be unemployed - relied on social benefits (unemployment insurance); as their benefits dried up, they began to consider going abroad and the safest option was to return to their country of birth.

Among Latin Americans, those from Bolivia and Ecuador led this trend, and also featured among those emigrating to an unknown destination, together with Brazilians, Argentinians, Venezuelans, and Uruguayans. In general, the odds for migrating to a non-EU28 country were very low, except for Cubans $(1.8 \%$ higher risk than Ecuadorians) (Table A-3 in the Appendix). Previous research has suggested that this could be due to the existence of a large and consolidated social network of Cubans in the United States, which could serve as a pull factor for the Cuban diaspora (Recaño, Roig, and de Miguel 2015).

The African, Asian, and Pacific Islander populations residing in Spain showed negative marginal effects in comparison to Europeans regarding the odds of experiencing return migration or emigration to an unknown destination. On the contrary, the marginal effects of the Latin Americans did not significantly differ from the Europeans', the reference group. This result qualifies our hypothesis, pointing to Latin Americans as a group that, on average, led return migration or other forms of international emigration (Figure 5). The multivariate analysis shows that once we consider the effect of sex, age, citizenship, and contextual variables, our initial hypothesis holds only for both forms of remigration, for which we found a minuscule but positive marginal effect of being Latin American in comparison to European. Nevertheless, Europeans are a very heterogeneous group, composed of highly qualified 
workers and retirees from the most developed countries of the European Union and low-skilled workers from the countries of eastern Europe. Compared to Latin Americans with their more homogeneous work characteristics, these differences end up making it difficult to compare patterns of behaviour between the two.

Spanish citizenship increased the chances of experiencing any kind of internal migration or international emigration to known destinations, while for those with other passports - that is, non-EU28 or EU28 citizenship - the marginal effect of leaving Spain without reporting any destination increased by about $52 \%$ and $44 \%$ respectively (Table A-2 in the Appendix). The former is the greatest effect found in the multivariate analysis of migration responses for all foreign-born populations. It may be that, given the characteristics of the data, foreign-born individuals with Spanish citizenship have greater incentives to report their return or remigration because, for example, they may receive a Spanish Social Security subsidy and/or because they intend to exercise their right to vote abroad. We must recall that this outcome, which applies to those reporting a migration destination, represents less than one-fifth of all the international movements of foreign-born individuals recorded by the Residential Variation Statistics. Among Latin Americans, the negative effect of any form of non-Spanish citizenship on return migration is also greater for other EU28 citizenships - mostly Italian and Portuguese than the effect of non-EU citizenship (Figure 6).

Before discussing the findings for the covariates relating to the region of departure, we should acknowledge two things. First, their effects are significantly minor compared to those for individual characteristics. Second, the effect found in the estimates of the probability of emigration to an unknown destination and interregional migration are greater than for the other types of migration studied here.

The marginal effects for unemployment rates show a positive effect on the odds of experiencing interregional migration as unemployment rates for both sexes of foreignborn individuals increase. Conversely, a one-unit increase in Spanish male unemployment rate reduces the probability of the foreign-born population changing their autonomous community of residence for an average individual by approximately $3.5 \%$ (Table A-2 in the Appendix). A one-unit increase in the Spanish male unemployment rate increases the probability of return migration over internal migration by approximately $0.1 \%$, but the same increase in female unemployment rates - for those of any origin - slightly reduces the likelihood of return by $0.2 \%$ for foreign female unemployment and $0.3 \%$ for Spanish female unemployment (Table A-2 in the Appendix). This is one more proof that the Spanish labour market is segmented by sex, birthplace, and citizenship. Additionally, there is an interaction between region of origin, unemployment, and migration that is not addressed. The interregional migration rates from the autonomous communities of the south, which were the most affected by unemployment during the crisis, are surprisingly low. Conversely, the high emigration 
rates associated with high unemployment rates - which again particularly affected the southern regions - could be due to the origins of the immigrants in the south of Spain, mostly led by newly arrived Africans and Latin Americans. These groups might be more oriented to international emigration than to interregional migration.

The activity rates were included in the modelling as predictors of the pressure on the labour market. In this respect, greater pressure results in greater odds of experiencing international emigration. Bearing this in mind, we included the most important economic sectors for male and female immigrants: that is, construction, services, agriculture, and manufacturing. According to our findings, the pressure in both sexes' activity rates had the expected effect on emigration to an unknown destination, while the pressure on female activity rates (manufacturing and services) triggered emigration to the European Union (Figure 6).

The hourly wage of dependent workers is the regional variable with the largest effect within the group of contextual variables for both models concerning foreign-born populations (Figures 5 and 6). As expected, an increase in the hourly wage reduced the odds of experiencing internal and return migration. However, a one-unit increase in hourly wage increased the odds of experiencing international emigration to an unknown destination by approximately $7.6 \%$, which was also true for Latin Americans (Table A2 and A-3 in the Appendix). At the same time, a similar increase in hourly wage had little or no effect on the odds of experiencing remigration for the foreign-born population, except for Latin Americans, in which case a one-unit increase raised the odds of both forms of remigration by approximately $0.1 \%$. In this sense, it is important to note that we have not analysed the effect of salaries by sector. In a segmented labour market such as that in Spain, formal employment might experience less intense wage variations, but we know that there could be a reduction in the wages of immigrants, who would try to find employment within the informal economy.

An increase in the GDP per capita has a negative but minuscule effect on predicting emigration to unknown destinations for all foreign-born populations and has no significant effect on predicting any form of international remigration, while it promotes interregional and return migration. The effects on return migration and emigration to unknown destinations are also true for Latin Americans (Tables A-2 and A-3 in the Appendix).

Finally, the effect of social networks, captured by the log of the foreign-born population from the same country of origin, shows that when the population of such a group is larger, the probability of experiencing return or internal migration decreases, while the odds of leaving Spain in any other form increase. This runs counter to our expectation that social networks would have a protective effect against any form of international emigration, but coincides with our expectations regarding interregional and return migration. Again, these results hold for all foreign-born groups, including 
Latin Americans (Tables A-2 and A-3 in the Appendix). However, there is another possible explanation for this result. The economic success of immigrants is closely related to their length of residence and their roots in Spain. As we have been able to check repeatedly, immigrants who prefer to leave Spain without reporting their destination do not have Spanish citizenship, a characteristic that leads us to believe that their stay in Spain was short. For such immigrants, the effect of social networks would be practically nonexistent and so they would not experience the protective effect of the networks initially found for interregional and return migration.

\section{Conclusions}

In this article, we have described the intensity and the determinants of the different migration responses adopted by the foreign-born population in Spain between 2006 and 2013 - before the crisis, during its onset, and in the recession. The main purpose of this analysis has been to assess when these different types of migration occurred and which populations preferred which types of international emigration from Spain as opposed to long-distance internal migration.

Our findings suggest, somewhat contrary to what we expected from our first hypothesis, that the decline in interregional migration rates continued for most of the foreign-born population during the recession. However, in accordance with our hypothesis, we found a two-stage decline among the Latin American population: first, a sharp decline in 2009-2010 and then a more gentle decline in 2011-2013. This pattern was not exclusive to Latin Americans, being identified among other foreign-born populations. One of the most outstanding findings, though, was that the foreign-born population with non-Spanish citizenship, regardless of birthplace, reduced their level of interregional migration in response to economic hardship and, once the recession was firmly established, their reluctance regarding long-distance internal mobility became a permanent feature. This two-stage trend could have been a response to a selection effect: those who lost their jobs first might have been part of a group of less wellestablished immigrants who had not been in Spain long enough to acquire Spanish citizenship.

Whereas interregional migration has declined, all forms of international emigration have increased following the crisis, although the preferences for the type of international emigration adopted varied by birthplace and citizenship. Return migration continued growing from 2008 to 2013 among Europeans and Latin Americans with Spanish citizenship, whereas it increased soon after the beginning of the crisis and stagnated during the recession for the rest of the foreign-born population. Onward international mobility, including its two forms (remigration to EU28 countries and 
remigration to non-EU28 countries), increased during the recession. However, during the initial stages of the crisis, this kind of migration grew at a slower pace. The latter grew significantly for all foreign-born individuals, but the former was mostly a marginal response with the exception of Cubans. The other form of emigration discussed here involves outflow to an unknown destination. This type of international emigration introduces the largest differences by country of origin in terms of migration responses adopted during the crisis. According to the bivariate analysis of migration rates, emigration to an unknown destination first grew among Latin Americans from 2006-2008 to 2009-2010, but it later declined during the recession. In contrast, the growth of this type of emigration from Spain has been constant throughout all periods for the rest of the foreign-born populations. However, the results of the multivariate analysis show that the behaviour of Europeans and Latin Americans did not differ much; the predicted probabilities derived from the multinomial regression show similar odds and pace of change throughout all periods. Thus, Latin Americans are not as specific a group as we hypothesized at the beginning of this article, and their patterns of behaviour resemble those of Europeans in this regard. It is worth noting, though, that Europeans are a more heterogeneous group than Latin Americans, as they include both highly skilled workers and retirees from central and northern Europe, as well as lowskilled workers from eastern European countries.

In the multivariate analysis of the characteristics that cause migrants to 'prefer' different forms of international emigration over interregional migration, we showed that the various stages of the economic cycle had transformed migrants' preferences.

With reference to the individual characteristics that are positively associated with the different forms of international emigration, we found that sex, age, birthplace, and citizenship have different effects, depending on the type of migration considered. First, return migration and international emigration to an unknown destination are typically male migration responses, whereas migration to another EU28 country and interregional migration have a more balanced composition with respect to sex.

Second, return migration, remigration to non-EU28 countries, and emigration to an unknown destination all share similar age profiles, which are concentrated in the advanced age groups. The odds of return migration and emigration to an unknown destination are especially high among people aged 60 or older, which could be due to a strategy to optimize economic resources, especially given that older people consume fewer familial resources at their place of origin. By contrast, remigration to the EU28 countries is more likely among adults under 45 years of age. Third, origin - defined according to place of birth - shows that Europeans have the highest likelihood of returning to their country of origin or leaving Spain without reporting their arrival or departure. Latin Americans, despite their lower probability of experiencing these types of migration compared to Europeans, have a significantly higher likelihood - especially 
regarding emigration to an unknown destination - of doing so than Africans, Asians, and Pacific Islanders. Among Latin Americans, Bolivians stand out as the people with the highest odds of preferring return to interregional migration. Bolivians, together with Brazilians, also led in emigration to unknown destinations. It should be acknowledged that Bolivians, Brazilians, and Paraguayans are, in fact, among those who arrived later in Spain compared to other Latin Americans. However, we cannot say that these two patterns of behaviour are exclusive to recently arrived groups since we also found a high propensity of emigration to unknown destination among long-established groups such as Argentinians and Uruguayans. Nevertheless, we can argue that the latter are very likely to have not acquired Spanish citizenship - and here we need to recall that we are considering emigration to an unknown destination, which is a typical response of non-Spanish citizens - and so to be in a more precarious economic situation in Spain.

Africans, along with Peruvians, Brazilians, and Colombians, are way more likely to migrate within the European Union. However, other Latin American groups constitute foreign-born populations with greater odds of migrating to a non-EU country. Cubans, for example, are especially likely to choose this form of mobility, as they already have relatively large communities in the United States. Fourth, non-Spanish citizens (from both EU28 and non-EU28 countries) preferred emigration to an unknown destination to any other migration responses when compared to Spanish citizens. It is worth noting that this result reflects a net effect for the entire period from 2006 to 2013, which includes increases and decreases for these flows, and that it is more an outcome of an observation effect than an actual finding. It is not that non-Spanish citizenship inhibits return migration or remigration; instead, as previously noted, Spanish citizens (foreign- or Spanish-born) may have greater incentives to report their departure from Spain. This explains why non-Spanish citizens have a higher chance of choosing emigration without reporting their departure from Spain to a Spanish municipality or their arrival in a new country to a Spanish consulate abroad. ${ }^{13}$

With regard to the determinants of the region of departure, the findings suggest that their effect on the type of migration response adopted was minor when compared to the size and significance of the individual characteristics. However, male unemployment - whether of Spanish or non-EU citizens - contributed to the increase in all international emigration responses when compared to interregional migration. Sector activity rates, especially for construction and services, were another predictor of remigration. The impact of hourly wages or the same-origin population concentration did not show any significant systematic effect. The almost zero effect of social support networks on inhibiting emigration could be interpreted in two ways. First, it could denote the inability of social networks to stop remigration in a context of widespread economic deterioration. Second, the effect of social networks is scarcely perceptible

\footnotetext{
${ }^{13}$ See Table A-1 in the Appendix.
} 
when using region as the level of analysis and might be better captured on a smaller scale (province or municipality).

In short, and with regard to the second hypothesis introduced at the beginning of this paper, we find that emigration to an unknown destination, which represents approximately $80 \%$ of the total emigration that occurred among the foreign-born population between 2006 and 2013, shares a similar demographic profile with return migration with respect to sex, age, and origin and follows a similar trend throughout all periods. The features that separate these two types of migration response relate to the effect of contextual variables at regional level and citizenship; except for these features, our findings denote emigration to an unknown destination as a form of international emigration possibly mainly driven by return migration. However, although this may support our second hypothesis, further research should be conducted to fully test it.

We conclude that return migration and departure from Spain to an unknown destination are more associated with the economic recession, whereas long-distance internal migration - although it declined during the onset of the crisis - was the initial reaction to the economic collapse. This result confirms our first hypothesis to a certain extent. First, internal mobility was preferred to return migration or other forms of emigration from Spain at the beginning of the economic crisis, despite descriptive data showing that this type of migration has declined since 2009. According to our second hypothesis, return migration and emigration to an unknown destination - which behave similarly to return migration in the multivariate analysis - significantly grew during the recession (2011-2013) among Latin Americans, but this hypothesis does not hold for all foreign-born populations, for whom only emigration to unknown destination grew in this period. It could be that while the numerous Latin Americans with Spanish or European citizenship were running out of unemployment subsidies, return migration emerged as a solution; in this same group, irregular immigrants without specific roots in Spain would have been incorporated in the large number of exits to unknown destination in the most difficult years of the crisis.

Finally, we need to consider the main limitations of this study. First, given the cross-sectional nature of the available statistics on migration flows to and from Spain, it is not possible to address causality in either the preferences or the chronological order in which individuals decide to migrate at the internal or international level. Second, the classification of origins we have used here does not take into account the heterogeneity of certain groups such as Europeans, whose composition considerably limits the explanation of their migratory patterns of behaviour. Thus, future research should distinguish between central and northern Europeans and eastern Europeans.

Here, we have limited the discussion to the main associations that depict the average profile of the migrants experiencing several types of mobility and the main historical trends. 
Given the lack of information on residence time in Spain, we have used Spanish and EU28 citizenship as proxies to explain the heterogeneity of the roots and vulnerability of Latin American immigrants. With the inclusion of this variable, we have been able to explain certain paradoxical responses, such as the high propensity of exits to unknown destination of Argentinians, Uruguayans, Paraguayans, Brazilians, and Bolivians in the most acute phases of the economic crisis. However, despite this and other limitations of the data used here, we want to emphasize that few countries in the world have collected in a single source the joint statistics for all types of mobility, which makes Spain a good place to explore the wide range of possible reactions by immigrants to economic crisis.

\section{Acknowledgements}

The research leading to this paper has received funding from the Spanish Ministry of Economy and Competitiveness under grant agreements CSO2013-45358-R (Grant Movilidad geográfica y acceso a la vivienda: España en perspectiva internacional) and CSO2016-79142-R (Comportamientos demográficos y estrategias residenciales: apuntes para el desarrollo de nuevas políticas sociales). The authors are immensely grateful to the reviewers for their valuable comments on an earlier version of the manuscript, although any errors are our own. 


\section{References}

Arslan, C., Dumont, J.C., Kone, Z., Moullan, Z., Ozden, Z., Parsons, C., and Xenogiani, T. (2014). A new profile of migrants in the aftermath of the recent economic crisis. Paris: Organisation for Economic Co-operation and Development (OECD Social, Employment and Migration Working Papers 160). doi:10.1787/181 5199X.

Aysa-Lastra, M. and Cachón, L. (2012). Latino immigrant employment during the Great Recession: A comparison of the United States and Spain. Norteamérica 7(2): 7-42.

Bayona-i-Carrasco, J., Thiers Quintana, J., and Avila-Tàpies, R. (2017). Economic recession and the reverse of internal migration flows of Latin American immigrants in Spain. Journal of Ethnic and Migration Studies 43(15): 24992518. doi:10.1080/1369183X.2017.1296354.

Bernardi, F., Garrido, L., and Miyar-Busto, M. (2011). The recent fast upsurge of immigrants in Spain and their employment patterns and occupational attainment. International Migration 49(1): 148-187. doi:10.1111/j.1468-2435.2010.00610.x.

Bertoli, S., Brücker, H., and Moraga, J.F.-H. (2013). The European crisis and migration to Germany: Expectations and the diversion of migration flows. Bonn: IZA Institute of Labor Economics (IZA Discussion Papers No. 7170).

Calnan, R. and Painter, G. (2016). The response of Latino immigrants to the Great Recession: Occupational and residential (im)mobility. Urban Studies 54(11): 2561-2591. doi:10.1177/0042098016650567.

Cebolla-Boado, H., Miyar-Busto, M., and Muñoz-Comet, J. (2015). Is the Spanish Recession increasing inequality? Male migrant-native differences in educational returns against unemployment. Journal of Ethnic and Migration Studies 41(5): 710-728. doi:10.1080/1369183X.2014.936837.

Cerrutti, M. and Maguid, A. (2016). Crisis económica en España y el retorno de inmigrantes sudamericanos. Migraciones Internacionales 8(3): 155-189.

Colectivo Ioé (1993). Rasgos generales y perfiles sociodemográficos de los principales colectivos. In: Giménez, C. (ed.). Inmigrantes extranjeros en Madrid. Tomo I. Panorama general y perfil sociodemográficos. 235. Madrid: Comunidad Autónoma de Madrid: 231-279. 
Czaika, M. (2012). Migration in times of uncertainty: On the role of economic prospects. Oxford: Oxford International Migration Institute (IMI Working Paper Series 52).

Czaika, M. and de Haas, H. (2012). The role of internal and international relative deprivation in global migration. Oxford Development Studies 40(4): 423-442. doi:10.1080/13600818.2012.728581.

Czaika, M. and de Haas, H. (2013). The effectiveness of immigration policies. Population and Development Review 39(3): 487-508. doi:10.1111/j.1728-4457. 2013.00613.x.

Domínguez-Mujica, J., Guerra-Talavera, R., and Parreño-Castellano, J.M. (2012). Migration at a time of global economic crisis: The situation in Spain. International Migration 52(6): 113-127. doi:10.1111/imig.12023.

Durand, J. and Massey, D.S. (2003). Clandestinos: Migración México-Estados Unidos en los albores del siglo XXI. Mexico City: Miguel Ángel Porrua.

Gil, F. (2010). Análisis de dos propuestas metodológicas para estimar las salidas de extranjeros en España: Las bajas por caducidad padronales y la renovación de las tarjetas de residencia temporales. Estadística Española 52(174): 277-309.

González-Ferrer, A. (2014). Retorno y reintegración de Latinoamericanos en Europa. In: FIIAPP (ed.). Propuestas para vincular las políticas de migración y empleo. Madrid: FIIAPP: 53-89.

IOM (2012). Impactos de la crisis sobre la población inmigrante. Madrid: International Organization for Migration.

King, R., Skeldon, R., and Vullnetari, J. (2008). Internal and international migration: Bridging the theoretical divide. Falmer: University of Sussex.

Koser, K. and Kuschminder, K. (2015). Comparative research on the assisted voluntary return and reintegration of migrants. Geneva: International Organization for Migration.

Larramona, G. (2013). Out-migration of immigrants in Spain. Population 222(68): 249-271. doi:10.3917/popu.1302.0249.

López de Lera, D. and Pérez-Carames, A. (2015). La decisión de retornar en tiempos de crisis: Una perspectiva comparada de los migrantes ecuatorianos y rumanos en España. Migraciones 37: 171-194. doi:10.14422/mig.i37.y2015.008. 
Mas-Giralt, R. (2016). Onward migration as a coping strategy? Latin Americans moving from Spain to the UK post-2008. Population, Space and Place 23(3): 112. doi:10.1002/psp.2017.

Mateos, P. (2015). Ciudadanía múltiple y migración: Perspectivas Latinoamericanas. Mexico City: CIESAS-CIDE.

Muñoz-Comet, J. (2014). ¿Qué trabajos ocupan quienes abandonan el desempleo? Diferencias entre españoles y extranjeros en un contexto de cambio económico. Revista Internacional de Sociología 72(2): 353-376. doi:10.3989/ris.2012.12.18.

Ortega, E., Domingo, A., and Sabater, A. (2013). El empadronamiento de la población extranjera en los municipios andaluces de 1998 a 2010. Cuadernos Geograficos 52(1): 232-263.

Pajares, M. (2010). Inmigración y mercado de trabajo: Informe 2010 del Observatorio de la Inmigración. Madrid: Observatorio Permanente de la Inmigración.

Pandit, K. (1997). Demographic cycle effects on migration timing and the delayed mobility phenomenon. Geographical Analysis 29(3): 439-450. doi:10.1111/j.15 38-4632.1997.tb00956.x.

Pereira, S. (2012). Immigrant workers' (im)mobilities and their re-emigration strategies. Employee Relations 34(6): 642-657. doi:10.1108/01425451211267937.

Prieto, V. and López Gay, A. (2015). Push and pull factors of Latin American migration. In: Domingo, A., Sabater, A., and Verdugo, R. (eds.). Demographic analysis of Latin American immigrants in Spain: From boom to bust. New York: Springer: 1-28. doi:10.1007/978-3-319-12361-5_1.

Quintero-Lesmes, D.C. (2016). Transformaciones territoriales de las migraciones internas de los latinoamericanos en España en tiempos de crisis económica. Scripta Nova 20(549): 1-27.

Recaño, J. (2016). La consolidación de las migraciones internas de inmigrantes como factor estructural de la movilidad geográfica en España. Panorama Social 24: $49-71$.

Recaño, J. and Jáuregui, A. (2014). Emigración exterior y retorno de latinoamericanos desde España: Una visión desde las dos orillas (2002-2012). Notas de Población 99: 177-240.

Recaño, J. and de Miguel, V. (2012). The internal migration of foreign-born population in Southern Europe: Demographic patterns and individuals determinants. In: 
Finney, N. and Catney, G. (eds.). Minority internal migration in Europe. Farnham: Ashgate: 239-262.

Recaño, J., Roig, M., and de Miguel, V. (2015). Spain: A new gravity centre for Latin American migration. In: Domingo, A., Sabater, A., and Verdugo, R. (eds.). Demographic analysis of Latin American immigrants in Spain: From boom to bust. New York: Springer: 181-209.

Recaño, J. and Roig, M. (2006). The internal migration of foreigners in Spain. Paper presented at the 2006 European Population Conference, Liverpool, UK, June 20-23, 2006.

Rodríguez-Planas, N. and Nollenberger, N. (2014). A precarious position: The labor market integration of new immigrants in Spain. Washington, D.C.: Migration Policy Institute.

Silvestre, J. and Reher, D. (2014). The internal migration of immigrants: Differencies between one-time and multiple movers in Spain. Population, Space and Place 20: 50-65. doi:10.1002/psp.1755.

Thierry, X., Herm, A., Kupiszewska, D., Nowok, B., and Poulain, M. (2005). How the $U N$ recommendations and the forthcoming EU regulation on international migration statistics are fulfilled in the 25 EU countries. Paper presented at the XXV IUSSP International Population Conference, Tours, France, July 18-23, 2005.

Tilly, C. (2011). The impact of the economic crisis in international migration. Work, Employment and Society 25(4): 675-692. doi:10.1177/0950017011421799.

Torre-Cantalapiedra, E. and Giorguli, S. (2015). Las movilidades interna y de retorno de los varones migrantes mexicanos a Estados Unidos en perspectiva longitudinal (1942-2011). Revista Estudios Demográficos y Urbanos 30(88): 7 43. doi:10.24201/edu.v30i1.1484.

Torres-Pérez, F., Moncusí, A., and Esteban, F. (2013). Ciudadanía, convivencia multicultural y crisis: Análisis comparativo de dos barrios de Valencia. Paper presented at the XI Congreso Español de Sociología, Madrid, Spain, July 10-12, 2013.

Zimmermann, K.F. and Zaiceva, A. (2012). Returning home at times of trouble? Return migration of EU enlargement migrants during the crisis. Bonn: IZA Institute of Labor Economics (IZA Discussion Papers No. 7111). 


\section{Appendix}

\section{Table A-1: Migration flows by type of movement and share of international emigration in total migration by place of birth (annual average, Spain, 2006-2013)}

\begin{tabular}{lllllllllllllll}
\hline & \multicolumn{3}{l}{ Latin Americans } & \multicolumn{3}{c}{ Spanish } & \multicolumn{4}{c}{ Rest of foreign-born } & \multicolumn{3}{c}{ Total foreign-born } \\
Period & I & IE & \% IE & I & IE & \% IE & I & IE & \% IE & I & IE & \% IE \\
\hline 2006-2008 & 83,718 & 82,667 & 49.7 & 357,013 & 27,519 & 7.2 & 116,048 & 101,754 & 46.7 & 199,766 & 184,421 & 48.0 \\
$2009-2010$ & 78,793 & 130,607 & 62.4 & 344,154 & 36,567 & 9.6 & 106,607 & 181,625 & 63.0 & 185,399 & 312,231 & 62.7 \\
$2011-2013$ & 64,230 & 131,204 & 67.1 & 349,596 & 55,223 & 13.6 & 97,530 & 213,950 & 68.7 & 161,760 & 345,154 & 68.1 \\
\hline
\end{tabular}

Source: Own elaboration based on Residential Variation Statistics (National Statistics Office, 2006-2013).

Notes: I = interregional migration flow; IE = international emigration flow; \% IE = share of total migration (interregional + international emigration) that corresponds to international emigration. 
Figure A-1: Predicted probabilities of return migration by birthplace and citizenship (Latin American immigrants)
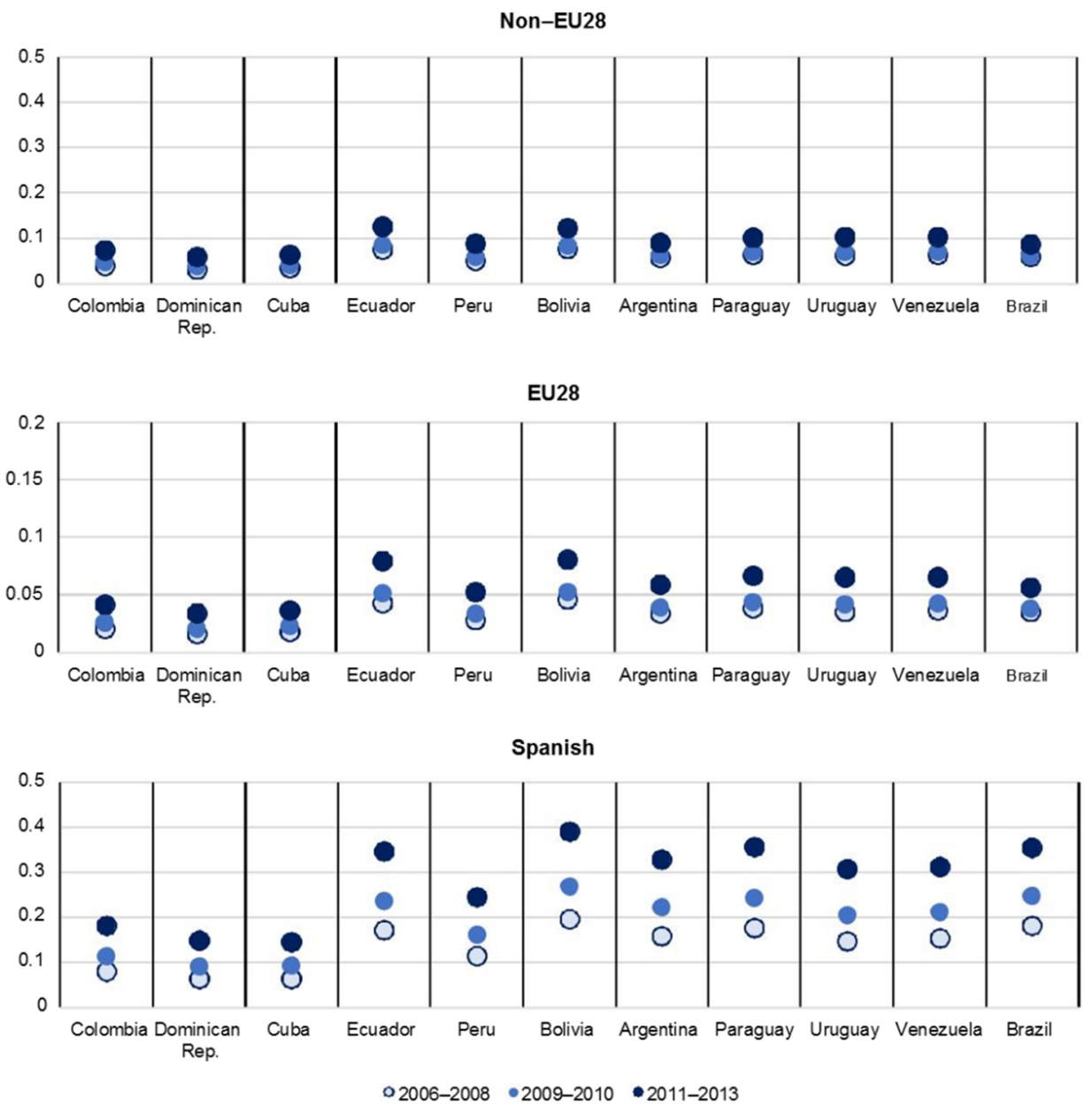

Source: Own elaboration based on estimates from multinomial regression for Latin American immigrants. 
Figure A-2: Predicted probabilities of emigration to another EU28 country by birthplace and citizenship (Latin American immigrants)

Non-EU28
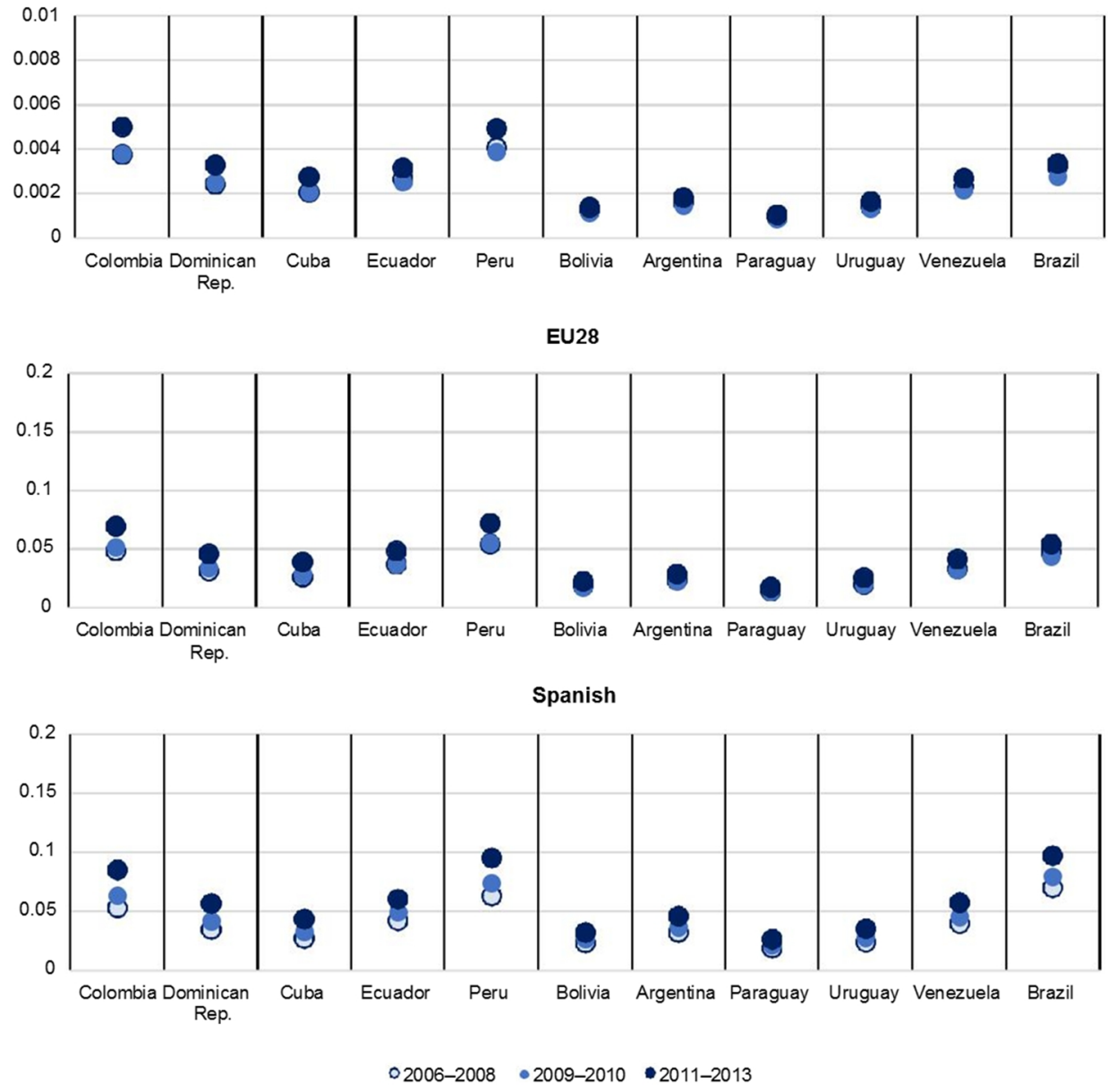

Source: Own elaboration based on estimates from multinomial regression for Latin American immigrants. 
Figure A-3: Predicted probabilities of emigration to non-EU28 country by birthplace and citizenship (Latin American immigrants)
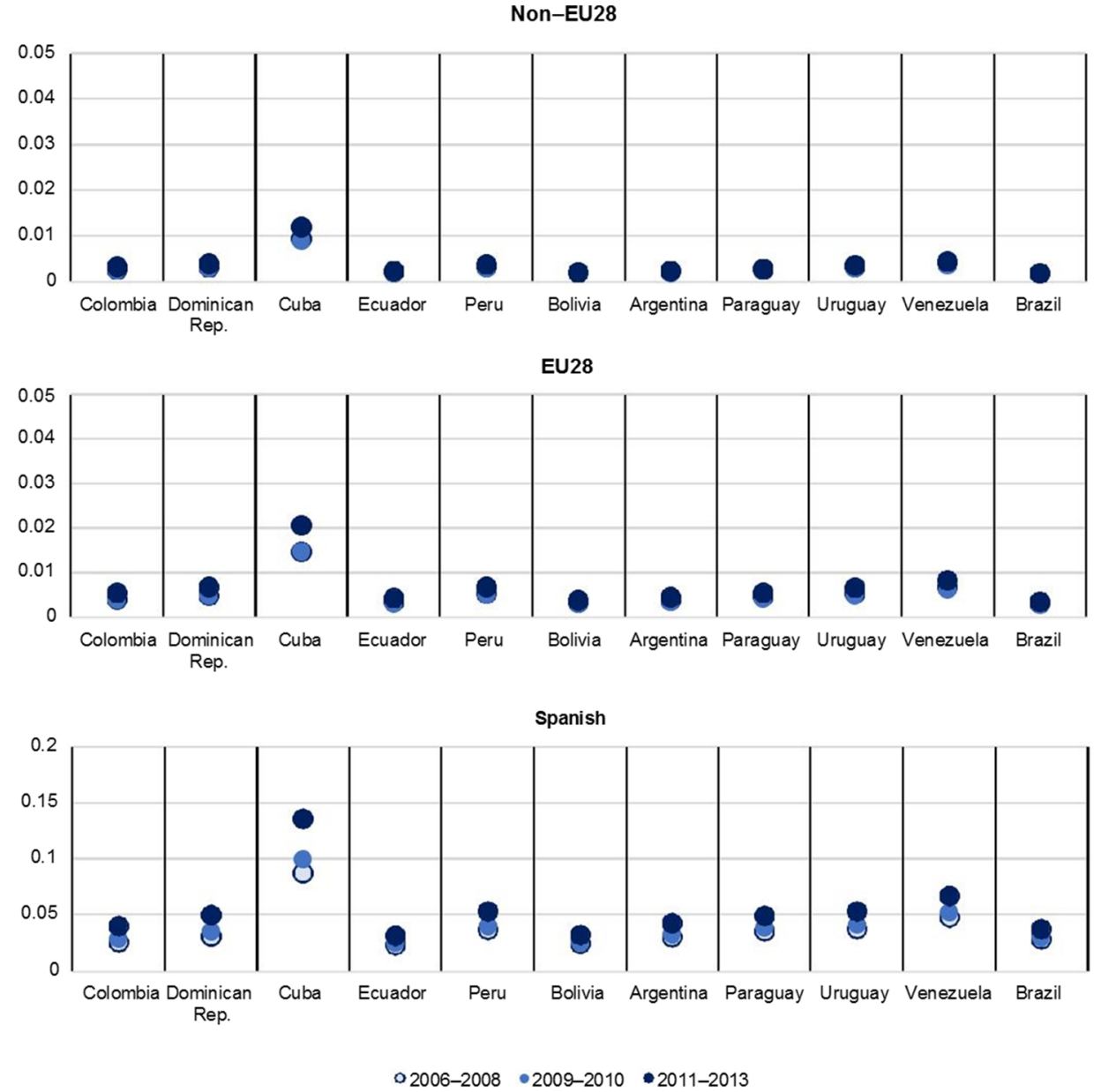

Source: Own elaboration based on estimates from multinomial regression for Latin American immigrants. 
Table A-2: Marginal effects from multinomial regression (ref. interregional migration, all foreign-born populations, 2006-2013)

\begin{tabular}{|c|c|c|c|c|}
\hline & \multicolumn{2}{|c|}{ Interregional migration } & \multicolumn{2}{|l|}{ Return } \\
\hline & $d y / d x$ & S.E. & $d y / d x$ & S.E. \\
\hline \multicolumn{5}{|l|}{ Sex (ref. male) } \\
\hline Female & $0.0417^{\star \star \star}$ & 0.0005 & $-0.00660^{\star \star \star}$ & 0.0003 \\
\hline \multicolumn{5}{|l|}{ Age (ref. 16-29) } \\
\hline $30-44$ & $-0.0195^{\star \star \star}$ & 0.0005 & $-0.00809^{\star * \star}$ & 0.0003 \\
\hline $45-59$ & $-0.0861^{* \star *}$ & 0.0008 & $0.00545^{\star \star \star}$ & 0.0004 \\
\hline $60+$ & $-0.240^{\star \star *}$ & 0.0013 & $0.0457^{* \star *}$ & 0.0005 \\
\hline \multicolumn{5}{|l|}{ Period (ref. 2006-2008) } \\
\hline 2009-2010 & $-0.0194^{\star * \star}$ & 0.0018 & $-0.00399^{\star \star \star}$ & 0.0010 \\
\hline 2011-2013 & $-0.0588^{\star \star \star}$ & 0.0024 & 0.00231 & 0.0013 \\
\hline \multicolumn{5}{|l|}{ Citizenship (ref. Spanish) } \\
\hline Non-EU28 & $-0.309^{\star \star *}$ & 0.0010 & $-0.0937^{\star \star *}$ & 0.0007 \\
\hline EU28 & $-0.290^{\star \star \star}$ & 0.0013 & $-0.0671^{\star \star \star}$ & 0.0008 \\
\hline \multicolumn{5}{|l|}{ Birthplace (ref. Europe) } \\
\hline Latin America & $0.0593^{\star \star \star}$ & 0.0010 & $-0.00242^{\star \star \star}$ & 0.0006 \\
\hline Africa & $0.143^{\star \star \star}$ & 0.0011 & $-0.0562^{\star * \star}$ & 0.0005 \\
\hline Asia and Pacific Islands & $0.182^{\star \star *}$ & 0.0012 & $-0.0664^{* \star *}$ & 0.0005 \\
\hline \multicolumn{5}{|l|}{ Unemployment rates } \\
\hline Non-EU female & $0.000839^{\star \star *}$ & 0.0001 & $-0.00146^{\star \star \star}$ & 0.0001 \\
\hline Spanish female & $0.0148^{\star \star \star}$ & 0.0002 & $-0.00276^{\star \star \star}$ & 0.0001 \\
\hline Non-EU male & $0.00408^{* * *}$ & 0.0001 & $0.000979^{* * *}$ & 0.0000 \\
\hline Spanish male & $-0.0347^{\star \star \star}$ & 0.0002 & $0.00115^{\star \star *}$ & 0.0001 \\
\hline \multicolumn{5}{|l|}{ Activity rates } \\
\hline Construction - male & $-0.0181^{\star \star \star}$ & 0.0002 & $-0.00442^{\star \star \star}$ & 0.0001 \\
\hline Agriculture - male & $-0.00807^{\star \star \star}$ & 0.0002 & $-0.00134^{\star \star \star}$ & 0.0001 \\
\hline Service - male & $-0.00493^{\star \star \star}$ & 0.0001 & $-0.00159^{\star \star \star}$ & 0.0001 \\
\hline Manufacturing - female & $-0.0241^{* \star *}$ & 0.0004 & $-0.00383^{\star \star \star}$ & 0.0002 \\
\hline Service - female & $-0.00421^{\star \star *}$ & 0.0003 & -0.000148 & 0.0001 \\
\hline Same-origin population (log) & $-0.0242^{\star \star \star}$ & 0.0004 & $-0.00292^{\star \star \star}$ & 0.0002 \\
\hline Hourly wage & $-0.0678^{* \star \star}$ & 0.0008 & $-0.00843^{\star \star \star}$ & 0.0004 \\
\hline GDP per capita & $0.00491^{\star \star *}$ & 0.0003 & $0.00113^{\star \star *}$ & 0.0002 \\
\hline
\end{tabular}


Prieto-Rosas, Recaño \& Quintero-Lesmes: Migration responses of immigrants during the Great Recession

Table A-2: (Continued)

\begin{tabular}{|c|c|c|c|c|c|c|}
\hline & \multicolumn{2}{|c|}{ Emigration to EU28 } & \multicolumn{2}{|c|}{ Emigration to non-EU28 } & \multicolumn{2}{|c|}{$\begin{array}{l}\text { Emigration to an unknown } \\
\text { destination }\end{array}$} \\
\hline & $\mathrm{dy} / \mathrm{dx}$ & S.E. & $\mathrm{dy} / \mathrm{dx}$ & S.E. & $\mathrm{dy} / \mathrm{dx}$ & S.E. \\
\hline \multicolumn{7}{|l|}{ Sex (ref. male) } \\
\hline Female & $0.000646^{\star * *}$ & 0.0001 & 0.0000422 & 0.0001 & $-0.0358^{\star \star \star}$ & 0.0005 \\
\hline \multicolumn{7}{|l|}{ Age (ref. 16-29) } \\
\hline $30-44$ & $0.00144^{\star * *}$ & 0.0001 & $0.00163^{* * *}$ & 0.0001 & $0.0245^{\star \star \star}$ & 0.0005 \\
\hline $45-59$ & $-0.000421^{\star *}$ & 0.0002 & $0.00246^{\star \star *}$ & 0.0001 & $0.0786^{\star \star *}$ & 0.0008 \\
\hline $60+$ & $-0.00340^{\star \star \star}$ & 0.0003 & $0.00370^{\star \star *}$ & 0.0001 & $0.194^{\star \star \star}$ & 0.0013 \\
\hline \multicolumn{7}{|l|}{ Period (ref. 2006-2008) } \\
\hline 2009-2010 & $-0.00263^{\star \star \star}$ & 0.0004 & $-0.00210^{\star \star \star}$ & 0.0003 & $0.0281^{\star \star \star}$ & 0.0018 \\
\hline 2011-2013 & $-0.00192^{\star \star \star}$ & 0.0005 & $-0.00180^{\star \star *}$ & 0.0004 & $0.0602^{\star \star \star}$ & 0.0024 \\
\hline \multicolumn{7}{|l|}{ Citizenship (ref. Spanish) } \\
\hline Extra-EU28 & $-0.0823^{\star \star *}$ & 0.0007 & $-0.0342^{\star \star \star}$ & 0.0004 & $0.519^{\star \star *}$ & 0.0004 \\
\hline EU28 & $-0.0535^{\star \star \star}$ & 0.0008 & $-0.0326^{\star \star \star}$ & 0.0004 & $0.443^{\star \star *}$ & 0.0009 \\
\hline \multicolumn{7}{|l|}{ Birthplace (ref. Europe) } \\
\hline Latin America & $0.00603^{\star \star *}$ & 0.0001 & $0.000535^{\star \star \star}$ & 0.0001 & $-0.0634^{\star \star \star}$ & 0.0010 \\
\hline Africa & $0.0344^{\star * *}$ & 0.0005 & $-0.00308^{\star \star *}$ & 0.0001 & $-0.118^{\star \star \star}$ & 0.0011 \\
\hline Asia and Pacific Islands & $0.0160^{\star \star *}$ & 0.0004 & $-0.000441^{*}$ & 0.0002 & $-0.131^{\star \star \star}$ & 0.0012 \\
\hline \multicolumn{7}{|l|}{ Unemployment rates } \\
\hline Non-EU female & $0.0000828^{\star \star \star}$ & 0.0000 & $-0.0000679^{\star \star *}$ & 0.0000 & $0.000603^{\star \star \star}$ & 0.0001 \\
\hline Spanish female & $-0.000636^{* * *}$ & 0.0000 & $-0.000294^{* \star \star}$ & 0.0000 & $-0.0111^{\star \star \star}$ & 0.0002 \\
\hline Non-EU male & 0.0000285 & 0.0000 & $0.0000409^{\star \star}$ & 0.0000 & $-0.00513^{* \star *}$ & 0.0001 \\
\hline Spanish male & $0.000820^{* * *}$ & 0.0001 & $0.000316^{\star \star \star *}$ & 0.0000 & $0.0324^{\star \star \star}$ & 0.0002 \\
\hline \multicolumn{7}{|l|}{ Activity rates } \\
\hline Construction - male & 0.0000116 & 0.0000 & $-0.0000729^{*}$ & 0.0000 & $0.0226^{\star \star \star}$ & 0.0002 \\
\hline Agriculture - male & -0.000054 & 0.0001 & $-7.27 \mathrm{E}-05$ & 0.0000 & $0.00954^{* * *}$ & 0.0002 \\
\hline Service - male & 0.0000247 & 0.0000 & $0.000122^{\star \star *}$ & 0.0000 & $0.00638^{* * *}$ & 0.0001 \\
\hline Manufacturing - female & $0.000249^{* *}$ & 0.0001 & $-8.15 \mathrm{E}-05$ & 0.0001 & $0.0278^{\star \star \star}$ & 0.0004 \\
\hline Service - female & $0.000202^{* \star *}$ & 0.0001 & $-8.86 \mathrm{E}-05$ & 0.0000 & $0.00424^{\star * *}$ & 0.0003 \\
\hline Same-origin population (log) & $0.000367^{* \star *}$ & 0.0001 & $-1.56 \mathrm{E}-05$ & 0.0001 & $0.0268^{* \star *}$ & 0.0004 \\
\hline Hourly wage & $0.000389^{*}$ & 0.0002 & 0.0000909 & 0.0001 & $0.0758^{* * *}$ & 0.0008 \\
\hline GDP per capita & 0.000105 & 0.0001 & $-1.35 \mathrm{E}-05$ & 0.0001 & $-0.00612^{\star \star *}$ & 0.0003 \\
\hline
\end{tabular}

Notes: ${ }^{\star} p<0.05,{ }^{\star \star} p<0.01,{ }^{\star \star \star} p<0.00$. Total number of cases included $(\mathrm{N}): 3,658,750$. 
Table A-3: Marginal effects from multinomial regression (ref. interregional migration, Latin American population, 2006-2013)

\begin{tabular}{|c|c|c|c|c|}
\hline & \multicolumn{2}{|c|}{ Interregional migration } & \multicolumn{2}{|l|}{ Return } \\
\hline & $\mathrm{dy} / \mathrm{dx}$ & S.E. & $\mathrm{dy} / \mathrm{dx}$ & S.E. \\
\hline \multicolumn{5}{|l|}{ Sex (ref. male) } \\
\hline Female & $0.0410^{\star \star \star}$ & 0.0008 & $-0.0132^{\star \star \star}$ & 0.0005 \\
\hline \multicolumn{5}{|l|}{ Age (ref. 16-29) } \\
\hline $30-44$ & $-0.0305^{\star \star \star}$ & 0.0009 & $0.00323^{* \star *}$ & 0.0006 \\
\hline $45-59$ & $-0.0918^{\star \star \star}$ & 0.0012 & $0.0165^{\star \star \star}$ & 0.0007 \\
\hline $60+$ & $-0.271^{\star \star \star}$ & 0.0022 & $0.0614^{\star * *}$ & 0.0010 \\
\hline \multicolumn{5}{|l|}{ Period (ref. 2006-2008) } \\
\hline $2009-2010$ & $-0.0317^{\star \star \star}$ & 0.0029 & $0.0193^{\star \star \star}$ & 0.0018 \\
\hline 2011-2013 & $-0.0894^{\star * *}$ & 0.0039 & $0.0505^{\star \star \star}$ & 0.0024 \\
\hline \multicolumn{5}{|l|}{ Citizenship (ref. Spanish) } \\
\hline Non-EU28 & $-0.283^{\star \star \star}$ & 0.0013 & $-0.141^{\star \star \star}$ & 0.0011 \\
\hline EU28 & $-0.190^{\star \star \star}$ & 0.0025 & $-0.169^{\star \star \star}$ & 0.0014 \\
\hline \multicolumn{5}{|l|}{ Birthplace (ref. Ecuador) } \\
\hline Cuba & $0.140^{\star \star *}$ & 0.0024 & $-0.0643^{* \star *}$ & 0.0011 \\
\hline Dominican Republic & $0.148^{\star \star \star}$ & 0.0020 & $-0.0673^{\star * *}$ & 0.0010 \\
\hline Argentina & $-0.0608^{\star \star \star}$ & 0.0016 & $-0.0244^{\star \star \star}$ & 0.0010 \\
\hline Bolivia & $-0.0522^{\star \star \star}$ & 0.0015 & $0.00354^{\star \star *}$ & 0.0011 \\
\hline Brazil & $-0.129^{\star \star \star}$ & 0.0016 & $-0.0224^{\star * \star}$ & 0.0011 \\
\hline Colombia & $0.123^{\star \star \star}$ & 0.0014 & $-0.0545^{\star \star \star}$ & 0.0008 \\
\hline Paraguay & $-0.0633^{\star * *}$ & 0.0020 & $-0.0143^{\star * *}$ & 0.0014 \\
\hline Peru & $0.0272^{\star \star \star}$ & 0.0018 & $-0.0367^{\star \star \star}$ & 0.0011 \\
\hline Uruguay & 0.00185 & 0.0025 & $-0.0198^{\star \star \star}$ & 0.0015 \\
\hline Venezuela & $-0.0251^{\text {***}}$ & 0.0021 & $-0.0182^{* * *}$ & 0.0012 \\
\hline \multicolumn{5}{|l|}{ Unemployment rates } \\
\hline Non-EU female & $0.00162^{* * *}$ & 0.0002 & $-0.00130^{\star \star \star}$ & 0.0001 \\
\hline Spanish female & $0.0129^{\star \star \star}$ & 0.0004 & $-0.00296^{\star \star \star}$ & 0.0002 \\
\hline Non-EU male & $0.00337^{\star * *}$ & 0.0001 & $0.000731^{\star \star \star}$ & 0.0001 \\
\hline Spanish male & $-0.0331^{\star \star \star}$ & 0.0004 & $0.00182^{\star \star \star}$ & 0.0002 \\
\hline \multicolumn{5}{|l|}{ Activity rates } \\
\hline Construction - male & $-0.0156^{\star \star \star}$ & 0.0004 & $-0.00478^{\star * \star}$ & 0.0002 \\
\hline Agriculture - male & $-0.00902^{\star \star \star}$ & 0.0004 & $-0.00106^{\star \star \star}$ & 0.0002 \\
\hline Service - male & $-0.00402^{\star \star \star}$ & 0.0002 & $-0.00121^{\star \star \star}$ & 0.0001 \\
\hline Manufacturing - female & $-0.0223^{\star \star \star}$ & 0.0006 & $-0.00239^{\star \star \star}$ & 0.0004 \\
\hline Service - female & $-0.00840^{\star \star \star}$ & 0.0004 & $0.000737^{\star \star}$ & 0.0003 \\
\hline Same-origin population (log) & $-0.0273^{\star \star *}$ & 0.0007 & $-0.00444^{\star \star \star}$ & 0.0004 \\
\hline Hourly wage & $-0.0531^{\text {***}}$ & 0.0013 & $-0.0122^{\star \star \star}$ & 0.0008 \\
\hline GDP per capita & 0.000567 & 0.0006 & $0.00334^{* * *}$ & 0.0003 \\
\hline
\end{tabular}


Prieto-Rosas, Recaño \& Quintero-Lesmes: Migration responses of immigrants during the Great Recession

Table A-3: (Continued)

\begin{tabular}{|c|c|c|c|c|c|c|}
\hline & \multicolumn{2}{|c|}{ Emigration to EU28 } & \multicolumn{2}{|c|}{ Emigration to non-EU28 } & \multicolumn{2}{|c|}{$\begin{array}{l}\text { Emigration to an unknown } \\
\text { destination }\end{array}$} \\
\hline & $d y / d x$ & S.E. & $d y / d x$ & S.E. & $\mathrm{dy} / \mathrm{dx}$ & S.E. \\
\hline \multicolumn{7}{|l|}{ Sex (ref. male) } \\
\hline Female & $0.00065^{\star \star \star}$ & 0.0002 & 0.000108 & 0.0002 & $-0.0285^{\star \star *}$ & 0.0008 \\
\hline \multicolumn{7}{|l|}{ Age (ref. 16-29) } \\
\hline $30-44$ & $0.00202^{\star * *}$ & 0.0002 & $0.00223^{\star * *}$ & 0.0002 & $0.0230^{\star \star \star}$ & 0.0009 \\
\hline $45-59$ & $-0.00155^{\star \star \star}$ & 0.0003 & $0.00214^{\star \star \star}$ & 0.0002 & $0.0747^{\star \star \star}$ & 0.0012 \\
\hline $60+$ & $-0.00783^{\star \star \star}$ & 0.0006 & $0.000819^{*}$ & 0.0003 & $0.217^{\star \star \star}$ & 0.0020 \\
\hline \multicolumn{7}{|l|}{ Period (ref. 2006-2008) } \\
\hline 2009-2010 & $-0.00363^{\star \star \star}$ & 0.0007 & $-0.00376^{\star \star \star}$ & 0.0006 & $0.0198^{* * \star}$ & 0.0028 \\
\hline $2011-2013$ & $-0.00301^{\star *}$ & 0.0009 & $-0.00287^{\star \star \star}$ & 0.0008 & $0.0447^{* * *}$ & 0.0039 \\
\hline \multicolumn{7}{|l|}{ Citizenship (ref. Spanish) } \\
\hline Extra-EU28 & $-0.0479^{* \star *}$ & 0.0006 & $-0.0346^{* * *}$ & 0.0005 & $0.506^{\star \star *}$ & 0.0005 \\
\hline EU28 & $-0.0120^{\star \star \star}$ & 0.0012 & $-0.0325^{\star \star \star}$ & 0.0006 & $0.404^{\star \star \star}$ & 0.0022 \\
\hline \multicolumn{7}{|l|}{ Birthplace (ref. Ecuador) } \\
\hline Cuba & $-0.00277^{\star \star \star}$ & 0.0004 & $0.0183^{\star \star \star}$ & 0.0006 & $-0.0916^{\star \star *}$ & 0.0023 \\
\hline Dominican Republic & $-0.000830^{*}$ & 0.0004 & $0.00289^{\star \star \star}$ & 0.0003 & $-0.0827^{\star * \star}$ & 0.0019 \\
\hline Argentina & $-0.00317^{\star \star \star}$ & 0.0003 & $0.00122^{\star \star *}$ & 0.0002 & $0.0872^{\star * \star}$ & 0.0016 \\
\hline Bolivia & $-0.00516^{\star \star \star}$ & 0.0004 & -0.00012 & 0.0003 & $0.0539^{\star \star \star}$ & 0.0014 \\
\hline Brazil & $0.00452^{* * *}$ & 0.0005 & 0.000379 & 0.0003 & $0.146^{\star \star \star}$ & 0.0015 \\
\hline Colombia & $0.00414^{\star \star *}$ & 0.0003 & $0.00135^{\star \star \star}$ & 0.0002 & $-0.0738^{\star \star \star}$ & 0.0013 \\
\hline Paraguay & $-0.00625^{\star \star \star}$ & 0.0005 & $0.00236^{\star * *}$ & 0.0005 & $0.0815^{\star \star \star}$ & 0.0018 \\
\hline Peru & $0.00558^{\star * *}$ & 0.0005 & $0.00342^{\star \star *}$ & 0.0003 & 0.000593 & 0.0017 \\
\hline Uruguay & $-0.00463^{\star \star \star}$ & 0.0004 & $0.00333^{\star \star *}$ & 0.0004 & $0.0192^{* * *}$ & 0.0024 \\
\hline Venezuela & $-0.000946^{\star *}$ & 0.0003 & $0.00555^{\star \star \star}$ & 0.0003 & $0.0387^{\star \star \star}$ & 0.0021 \\
\hline \multicolumn{7}{|l|}{ Unemployment rates } \\
\hline Non-EU female & $-0.0000902^{*}$ & 0.0000 & $-5.2 \mathrm{E}-05$ & 0.0000 & -0.00018 & 0.0002 \\
\hline Spanish female & -0.00014 & 0.0001 & $-0.000491^{\star \star \star}$ & 0.0001 & $-0.00935^{\star \star \star}$ & 0.0004 \\
\hline Non-EU male & $3.92 \mathrm{E}-05$ & 0.0000 & $5.18 \mathrm{E}-05$ & 0.0000 & $-0.00419^{\star \star \star}$ & 0.0001 \\
\hline Spanish male & $0.00068^{* * *}$ & 0.0001 & $0.000442^{* * *}$ & 0.0001 & $0.0302^{\star \star \star}$ & 0.0004 \\
\hline \multicolumn{7}{|l|}{ Activity rates } \\
\hline Construction - male & $-9.8 \mathrm{E}-05$ & 0.0001 & $-5.9 \mathrm{E}-05$ & 0.0001 & $0.0206^{\star * \star}$ & 0.0004 \\
\hline Agriculture - male & $0.000287^{\star \star}$ & 0.0001 & $0.000240^{\star *}$ & 0.0001 & $0.00955^{\star \star *}$ & 0.0004 \\
\hline Service - male & $0.000122^{*}$ & 0.0001 & $0.000169^{\star * \star}$ & 0.0000 & $0.00494^{\star * *}$ & 0.0002 \\
\hline Manufacturing - female & $0.00087^{\star \star *}$ & 0.0001 & -0.00014 & 0.0001 & $0.0240^{\star \star \star}$ & 0.0006 \\
\hline Service - female & $0.00064^{\star \star \star}$ & 0.0001 & $-4.9 \mathrm{E}-05$ & 0.0001 & $0.00707^{\star \star *}$ & 0.0004 \\
\hline Same-origin population (log) & 0.000113 & 0.0002 & $0.000820^{* * *}$ & 0.0002 & $0.0308^{* * *}$ & 0.0007 \\
\hline Hourly wage & $0.00093^{\star \star *}$ & 0.0003 & $0.00104^{\star \star \star}$ & 0.0003 & $0.0634^{\star \star *}$ & 0.0013 \\
\hline GDP per capita & -0.00022 & 0.0001 & $-0.000300^{\star *}$ & 0.0001 & $-0.00339^{\star \star \star}$ & 0.0006 \\
\hline
\end{tabular}

Note: ${ }^{*} p<0.05,{ }^{* \star} p<0.01,{ }^{* \star *} p<0.00$.. Total number of cases included $(\mathrm{N}): 1,339,066$. 